\title{
IN THE CONTEXT OF GLOBALIZATION AND INTERNATIONAL POLITICAL ECONOMICS THE EFFECTS OF TAX STRUCTURE ON POVERTY: TURKEY AND OTHER OECD COUNTRIES
}

\author{
Sibel ÇAŞKURLU \\ Dr., Gazi University, Department of Economics / TURKEY, E-Mail: sibelcas@gmail.com
}

Cem Barlas ARSLAN

Asst. Prof., Kırıkkale University, Faculty of Law / TURKEY

E-Mail: barlasarslan@gmail.com

Eren ÇAŞKURLU

Assoc.Prof., Gazi University, Department of Finance / TURKEY,

E-Mail: erencas@gmail.com

\begin{abstract}
The structural situation of the 21 st century in the world system is expressed as "globalization". This situation has a wide range of influence from state administration to politics, from economic operation to social development. When any element on the world scale is studied scientifically, the effects and consequences of the phenomenon of globalization must be taken into account. The International Political Economy (UPI), which has recently emerged from an important subdivision of the international economic sciences into an almost independent field, is predominantly examining the effects and consequences of the phenomenon of globalization. Based on the examination of state policies and the interaction of the global economy, UPI is the main axis of this work. Income
\end{abstract}




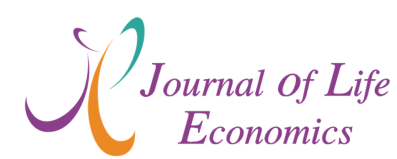

inequality, one of the drawbacks of the globalization process, and poverty, which has become a chronic problem, constitute one of the main issues of UPI. In this study, the effects of taxation on poverty, which is one of the most important of state policies, have been studied in the context of UPI.

Key Words: Globalization, Tax, Poverty

Jel Code: F65, H20, 132

\section{INTRODUCTION AND METHODOLOGY}

Tax practices have an indispensable place in state activities. According to the economic, social and political structure in place, the activities of the states that make indirect and direct interventions change with the necessity of the globalization of the capital (Caskurlu, 2011: 208). This study tries to assess the relation between poverty and governmental policies. But public expenditure and regulation based solutions will be lined off and only tax based suggestions will be discussed.It should not be forgotten that taxes have very important effects on increasing and / or reducing poverty (Demir, 2013: 105).

In this paper it is tried to find out some answers to these important questions:

\section{-How is the tax structure across OECD countries? (Does the level of tax burden increase?)}

-Do tax systems have some features that relief poverty or to the contrary? (Should taxes particularly be used for poverty reduction, wealth, employment etc? Which government activities are mainly financed by increased tax burden? What should be the optimal tax system for poverty reduction?)

In this paper, using a modified version of V. Tanzi's (1980) Diagnostic Tests for Tax Systems will help us understanding "optimal tax structure"and using the P. Bessard's (2009) Tax Oppression Index will also make possible to calculate "tax burden".

\section{Box 1.Diagnostic Tests for Tax Systems (V. Tanzi)}

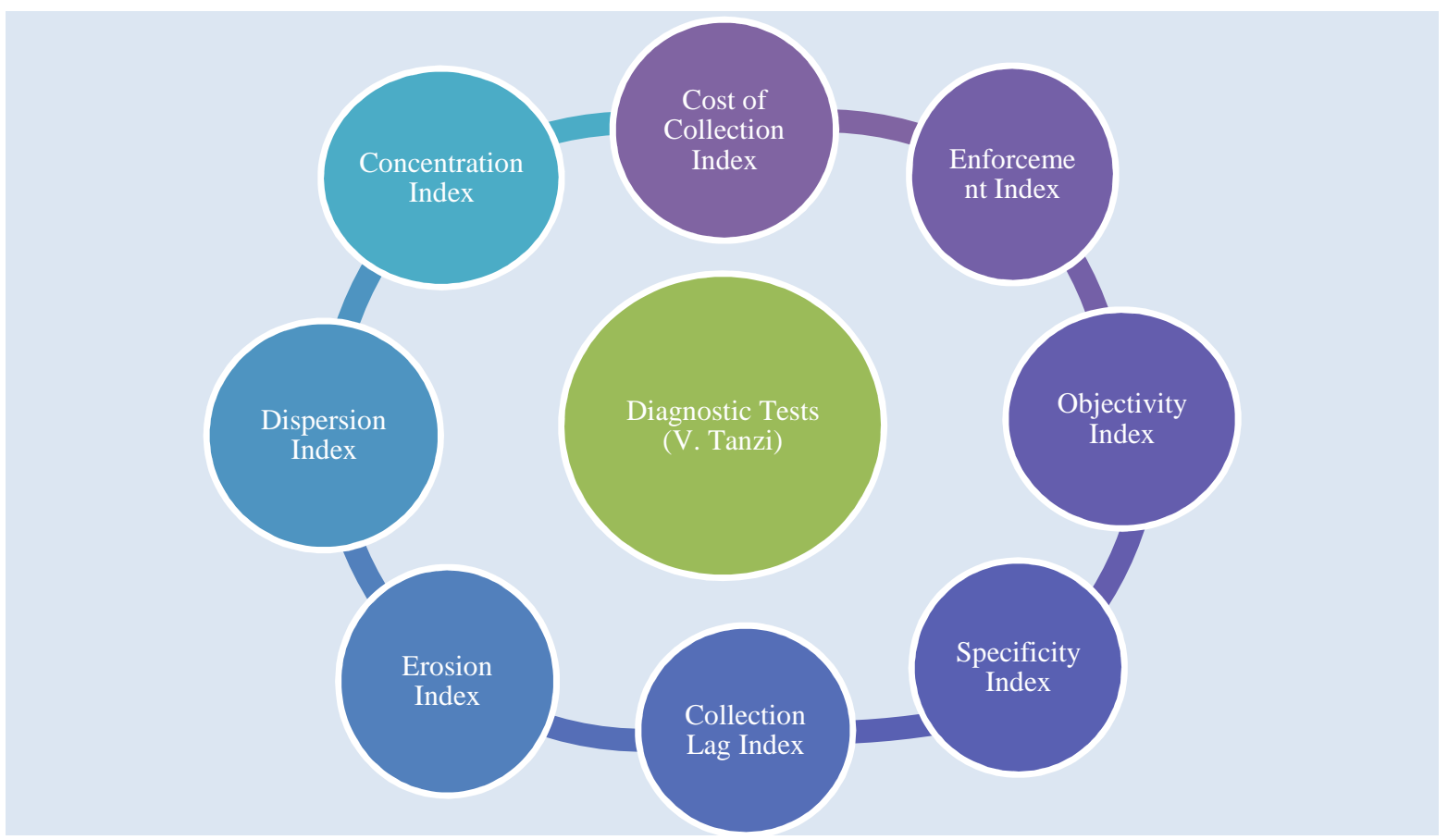

Source:(Tanzi, 1980: 24 - 29). 
In order to test the sensitivity of tax system to poverty; Concentration, Dispersion, Erosion and Specificity indexes will be used in this study (Tanzi, 1980: 24 - 29).

Box 2. Tax Oppression Index Calculation (P. Bessard)

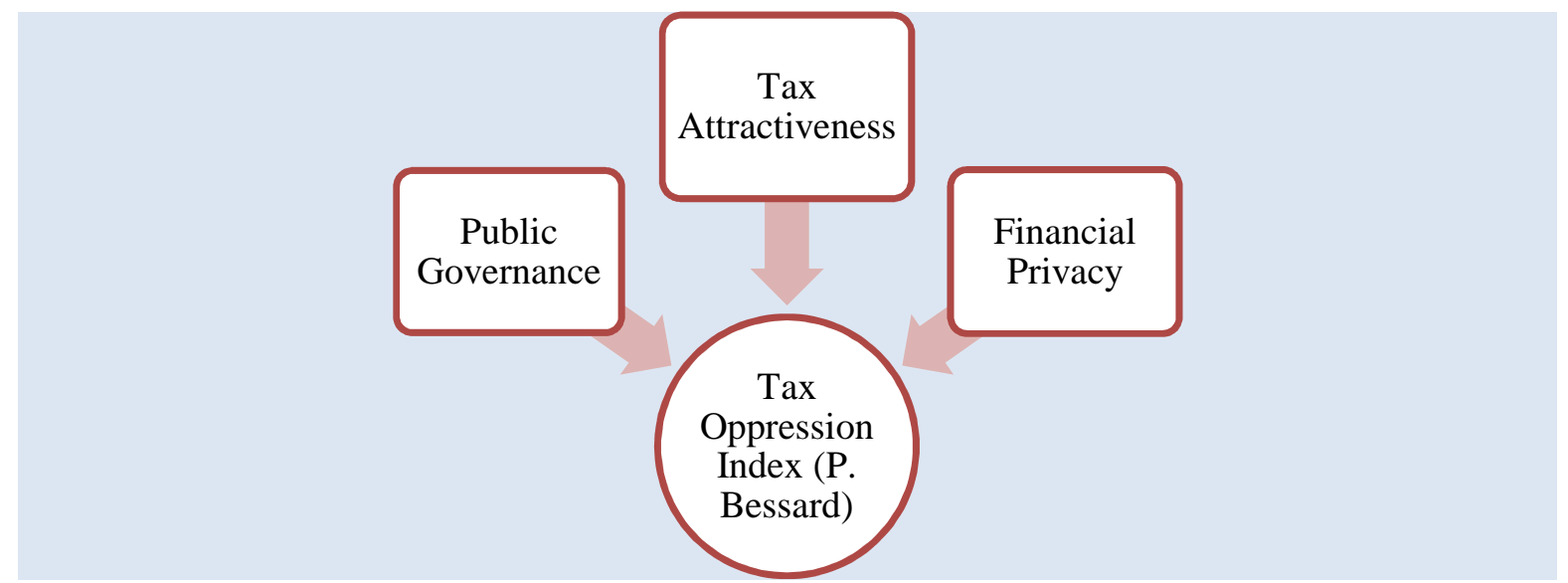

Source:(Bessard, 2009: 15).

In approaching effects of tax burden on the relation between labour and poverty, P.Bessrad's Tax Oppression Index will be taken into account. This index especially will be discussed within the framework of "unattractiveness" and "poverty sensitivity of taxes" in terms of poverty (Bessard, 2009: 15).

\section{GLOBALIZATION AND INTERNATIONAL POLITICAL ECONOMY}

International political economy is relatively a new area of research. It examines the dynamic interaction between state and market and how they shape each other (ÖnişandKutlay, 2014: 1). Interaction between a state and a market can be described somehow. While governments are trying to make use of the prosperity produced by the market for the power they are trying to achieve, capital owners are trying to use regulatory authority of states to further its wealth (Öniş and Kutlay, 2014: 2). Analytical application is proceeded via the combination of international and national relation and economics (Şen, 1998: 405).

The main features of the international political economy can be listed as follows ( $\mathrm{Al}$, 2015:147):

-Economic and political system work together.

-The development process is accelerated by globalization.

- It has an inherent structure.

Since the 1970s, it has been understood that the disciplines of international economics and international politics are intertwined, and the process of economic integration has become a common problem of politics and economics within the framework of the attempt to keep political control and become more and more common with globalization (Ateş and Gökmen, 2013). However, until the researches of "international political economy" field are performed, researchers those who deal with economics neglected the evaluate the interests of the state and also experts those who working in the policy field omitted the state and market relations (Ateş and Gökmen, 2013: 51). 


\section{LITERATURE REVIEW ABOUT RELATIONS BETWEEN POVERTY AND TAXATION}

There are many researches and studies subject on structures of taxation in countries. Also, many of them investigate the effects of taxation on economic structure. But very few studies addressed the effects of taxation on poverty.

In Özerkmen (2004) it is stated that unfair growth in the globalization process has led to impoverishment, and that unemployment in developing and underdeveloped countries has further increased (Özerkmen, 2004: 146). Hatipler (2017) also pointed out that the globalization process created an imbalance in the distribution of income, resulting in increasing poverty (Hatipler, 2017: 86). It is possible to say that due to income inequality and income injustice, poverty also exacerbated. In Ayyildiz (2017), it is stated that taxes can be one of the main reasons of income inequality (Ayyıldiz, 2017: 137).

Balseven states that even in the welfare state regime, the abolition of income inequality through taxation is at a limited level because it is indicated that the increasing proportion of income taxation affects low incomes in general (Balseven, 2017: 101). In Ocampo and Carmona (2015), it is stated that the existing global tax system has very serious negative effects on the poor (Ocampo and Carmona, 2015).

\section{TAX STRUCTURE AND TREND IN BURDEN LEVEL ACROSS OECD COUNTRIES}

\subsection{Tax Concentration - Tax BurdenRelationship and Effects}

The conditions, forms and characteristics of taxation are determined by law. The concept which expresses the relative share and importance of taxes within the total tax revenues or national income is called tax structure (Korkmaz, 1982: 21). In this study, tax burden on labour income is tried to evaluate first by using concentration and tax attractiveness indexes then by focusing on the informal economy interaction. The concentration index indicates, getting highest revenue with least number of taxes. In this analysis concentration on labour incomes will be discussed as a negative affected concentration index. Moreover, in Bessard (2009), an increase in total tax burden, decreases the tax attractiveness (Bessard, 2009: 15). An increase in tax burden on labour income will be dealt as tax unattractiveness in terms of labour income. 


\section{Graph 1. OECD Countries Tax Structure (Different Kind of Taxes Share of Total \%) 2005 - 2015 (Average)}

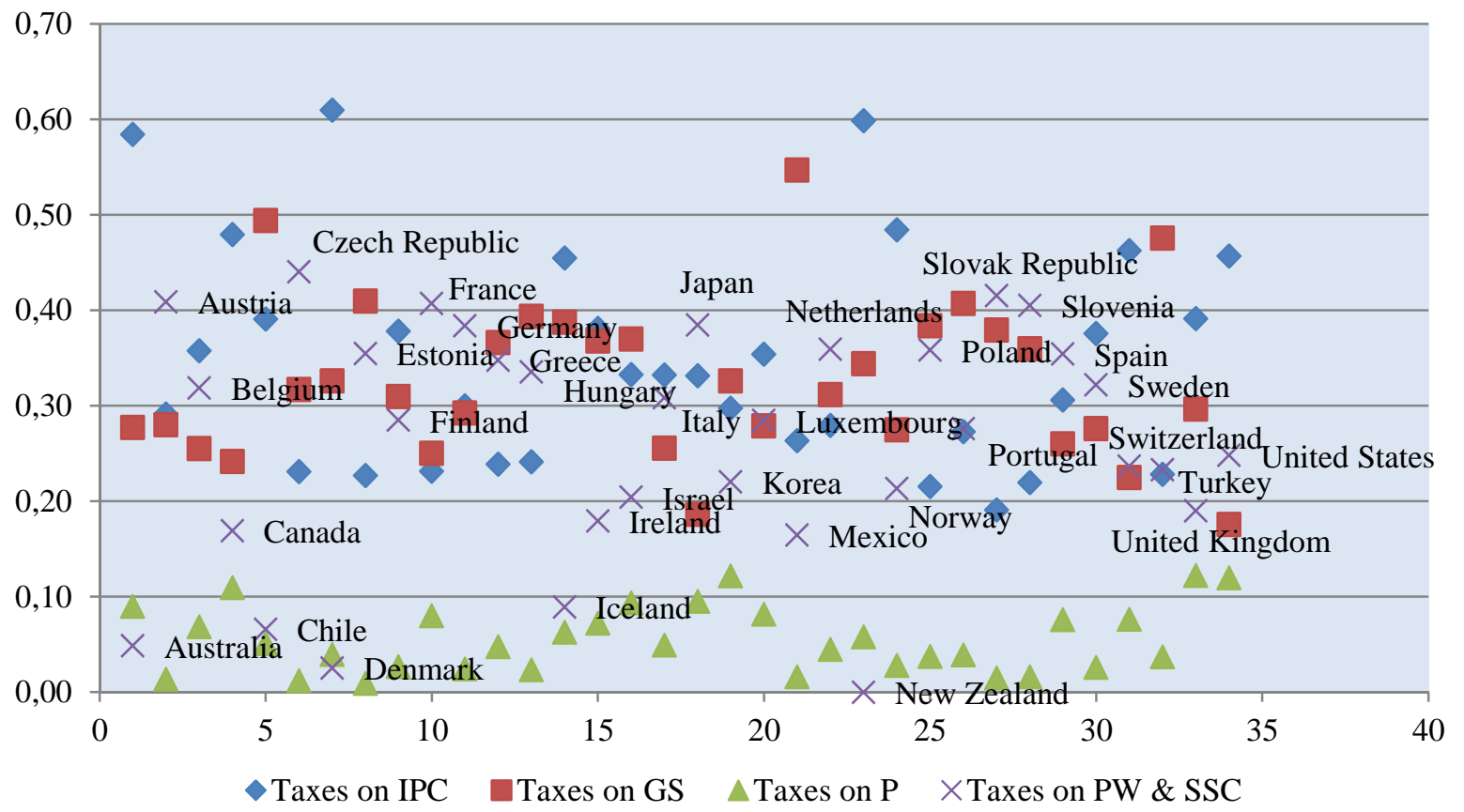

Source: (OECD Revenue Statistic, www.oecd-ilibrary.org/taxation/data/revenuestatistics/comparative-tables_data-00262-en, 09.09.2017)

Note: IPC: Income - Profit - Capital, PW: Payroll - Wages, GS: Good - Services, P: Property, SSC: Social Security Contribution

Graph (1) shows the OECD countries' tax structure in proportion to total taxes between the years 2005 and 2015. By comparing the ratio of Payroll taxes and SSC (labour taxes) in total tax revenues among different countries we can see that: Czech Republic, Slovakia, Austria, France and Slovenia have highest proportion (ratio). Other countries with high ratios are: Estonia, Germany, Japan, Netherlandsand Spain. Greece, Italy and Poland can be thought of as a secondary group. Because of its proportional character, SSC burden raises the total burden of labour taxes.

While other determinants are fixed, wage tax regulations within tax structure affect preferences to work (labor time) or not to work (leisure time) and bring income and substitution effects into existence. In Schneider et. al. (2010), it is mentioned that in nearly all studies about shadow economy, the tax and social security contribution burdens are among the main causes (Schneider et al. 2010: 5). Labour-leisure choices may be affected by taxes, so it causes to stimulate labor supply in the shadow economy and when the difference between the total labour cost and the after - tax earnings in the official economy is so high then the incentive towards avoidance of this difference comes to exist in the shadow economy (Schneider et al. 2010: 5).Because it causes labor costs to increase and changed working and leisure preferences of employees in favor of leisure time, tax burden on labor and the high share of social security contributions are considered to be one of the most important reasons for the formation and expansion of the informal economy (K1zılot and Comakl1, 2004: 123). 


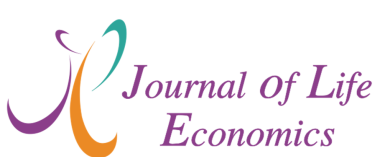

\section{Graph 2. Fiscal Freedom \& Shadow Economy Correlation (2007 - 2015 Growth rate)}

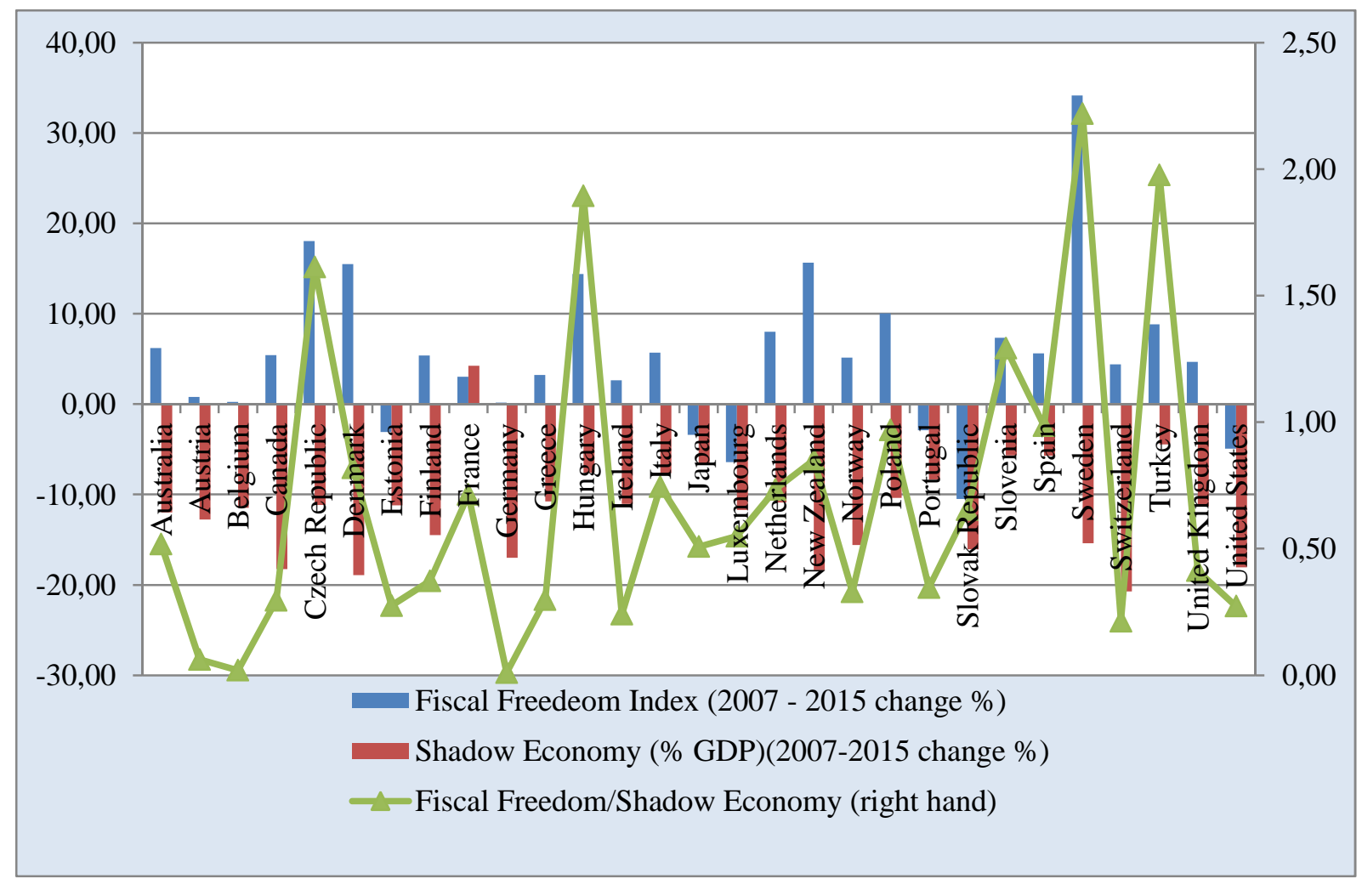

Source:(The Heritage Foundation, Economic Freedom Index, http://www.heritage.org/index/download, 01.10.2017)

Graph (2)shows the relation between fiscal freedom index - which shows the effects of total tax burden and public expenditures on economic decisions - and shadow economy index which is asub classification of Heritage Foundation Economic Freedom Index. A negative correlation is expected.We can see that Estonia, France, Germany, Hungary, Ireland, Israel, Japan, Luxembourg, Netherlands, Poland, Portugal, Slovenia, Sweden, Switzerland and UK have the expected correlation.

It's mostly seen that tax - benefit schemes in the tax systems are shaped by political economic forces rather than by well - designed social aims (Spadaro, 2008: 16). When the past periods are examined, it appears that the legal rate of wage tax has changed many times but has never fallen. The answer to the fact that the ratios of the wage rates are much easier than the income rate is partly due to the fact that the escape from the mentioned wages is very small compared to the others. The efficiency of each collected unit of these taxes is also high. Ineffective tax limits governments. In this respect, it is no coincidence that politicians in the major European states are reliant on relatively effective and broad-based taxes such as wage and spending taxes (Mulligan, 2005: 95-96).

Graph (3) shows the effect of tax burden on fiscal freedom index. In countries where this ratio is high above $50 \%$, index is negatively affected. This can be seen in counties like: Portugal, Israel, Slovenia, Germany, Spain, UK, Finland, Netherlands, Italy, France, Austria, Norway, Belgium, Sweden and Denmark. Especially countries such as Estonia, Poland, Slovenia, Sweden and UK have significant decreased level of fiscal freedom index by reason of their tax burden level. 


\section{Graph 3.The Interaction of the Tax Burden and the Fiscal Health Index} (2013 - $2017 \%$ change)

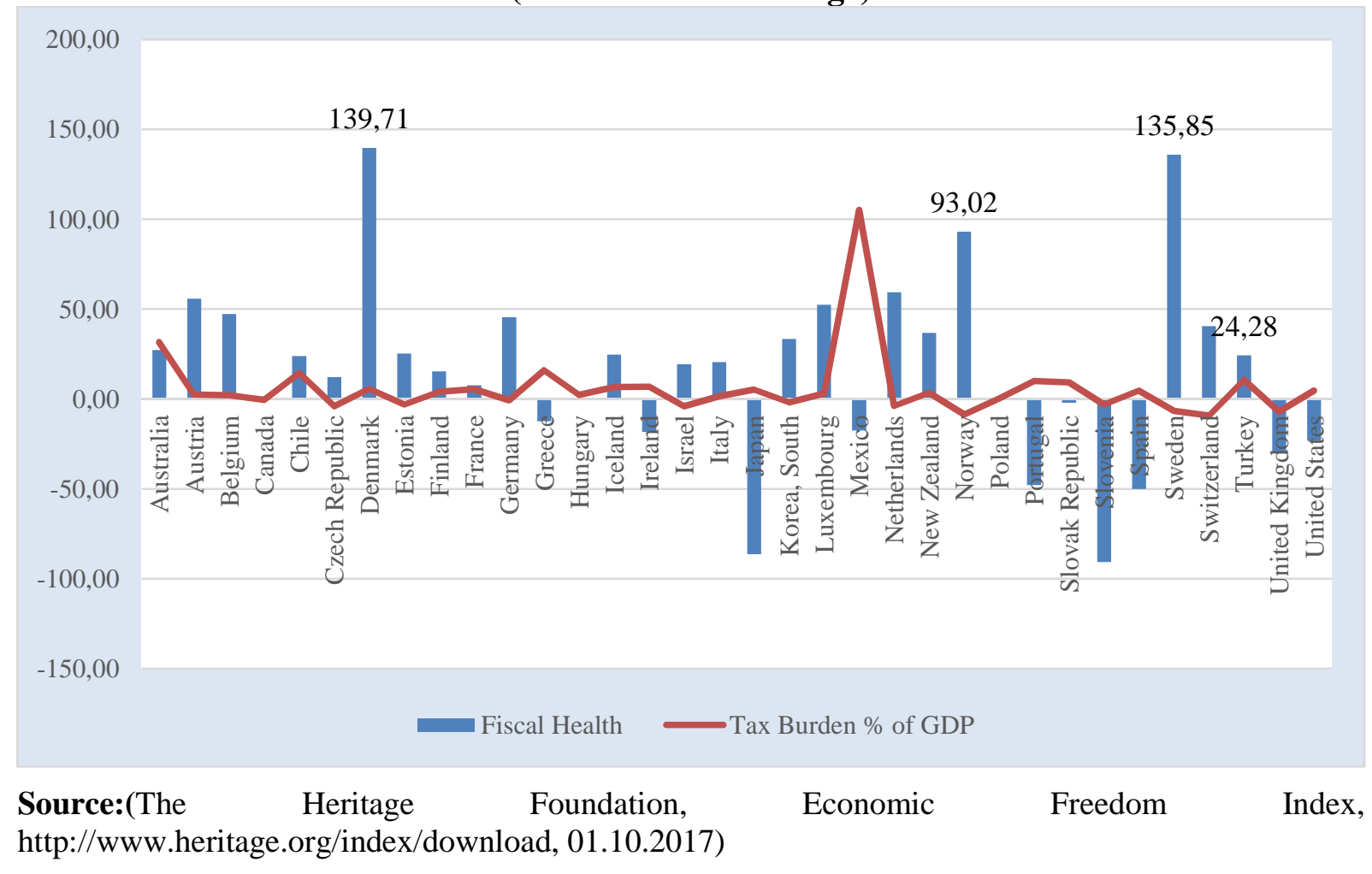

Sanchez (2011) shows experimentally that consumption taxes have an impact on labour taxes (Sanchez, 2011: 19). The five countries which heavily depend on consumption taxes in their tax structure are: Mexico, Turkey, Estonia and Portugal. The countries that also show the negative relation between consumption taxes and shadow economy in second Graphare: Estonia (Labour taxes \&consumption taxes), Hungary (only consumption taxes), Ireland (only consumption taxes) Poland (Labour taxes \&consumption taxes), and Slovenia (Labour taxes \&consumption taxes)

\subsection{Decomposition of Taxes - Tax Burden Relation}

The concept of decomposition of taxes, which indicates a valuation process by which different kinds of taxes can be classified among the whole system, makes it possible to comparethe trends of tax burden among different countries in between different years.In valuation and classification process of decomposition, Martin et. al. (2016)'s "The Global Competitiveness Index" will be used (Martin et. al. 2016: 41). Combining the Dispersion Index and Oppression Index, different point of views can be achieved by analysis of sorting. Country values that will be used in formula will be proportional to GDP.

Sorting and valuation formula is below:

$$
-6 * \frac{\left(\text { CountrySCore }_{j}{ }_{j}-\text { SampleMinimum }\right)^{(\text {SampleMaximum }- \text { SampleMinimum })}+7}{(1)}
$$




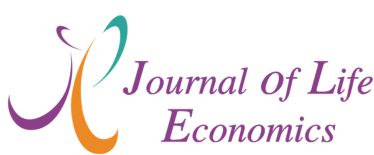

\section{Graph 4.Total Tax Burden Value Changing From 2001 to 2015}

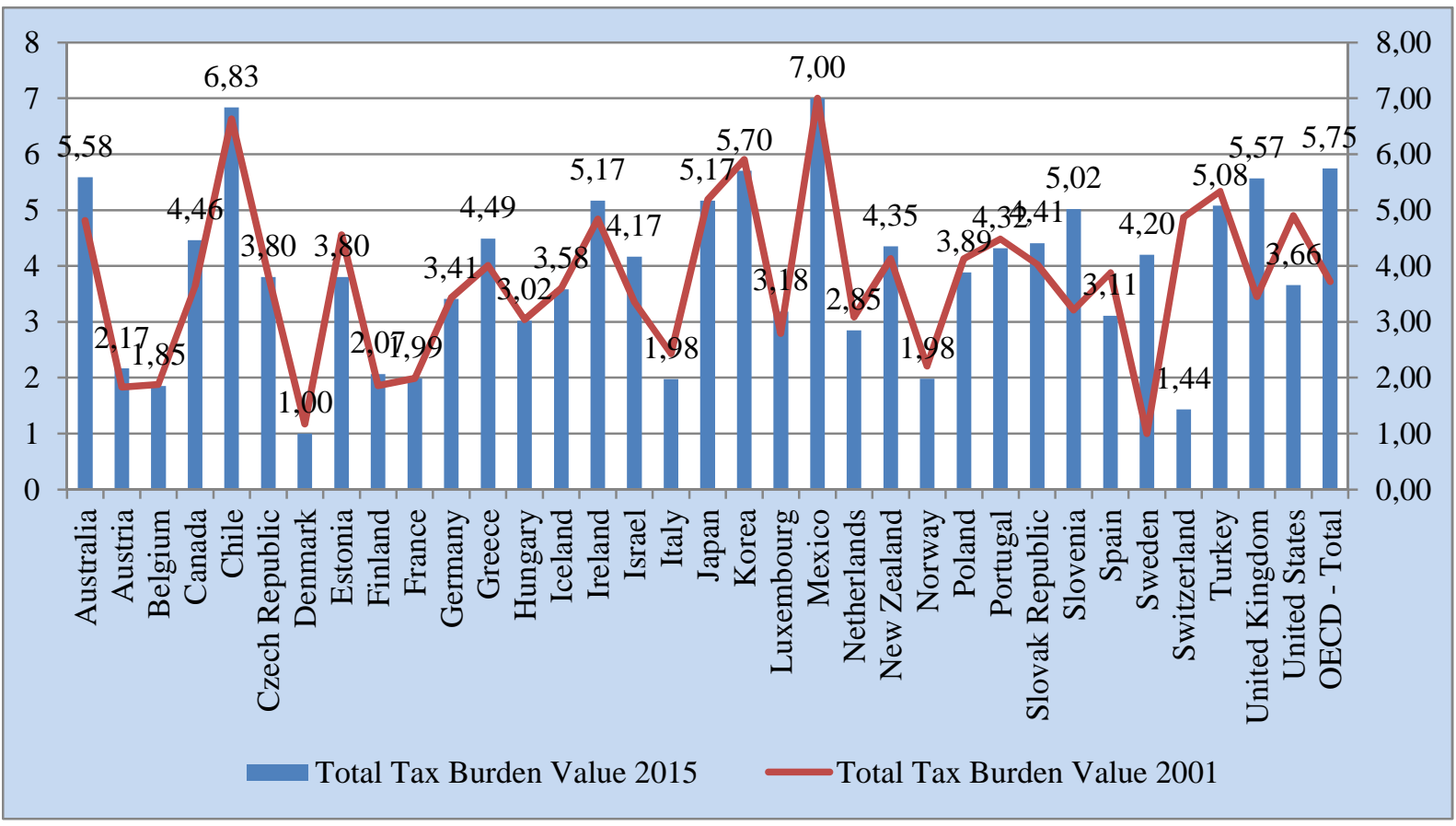

Source:(OECD Revenue Statistic, http://www.oecd-ilibrary.org/taxation/data/revenuestatistics/comparative-tables_data-00262-en, 09.09.2017)

Graph (4) shows the comparison of tax burdens between the years 2001 and 2015. In both years Mexico has the highest tax burden. Average OECD tax burden raised in years from 2001 to 2015. In this Graph it can be seen that in 19 of this 35 countries bar value is under the line value, meaning that tax burden has fallen (decreased). Denmark had the lowest tax burden in 2015.

\section{Graph 5.Payroll and Salary Tax Burden Value Changing From 2001 to 2015}

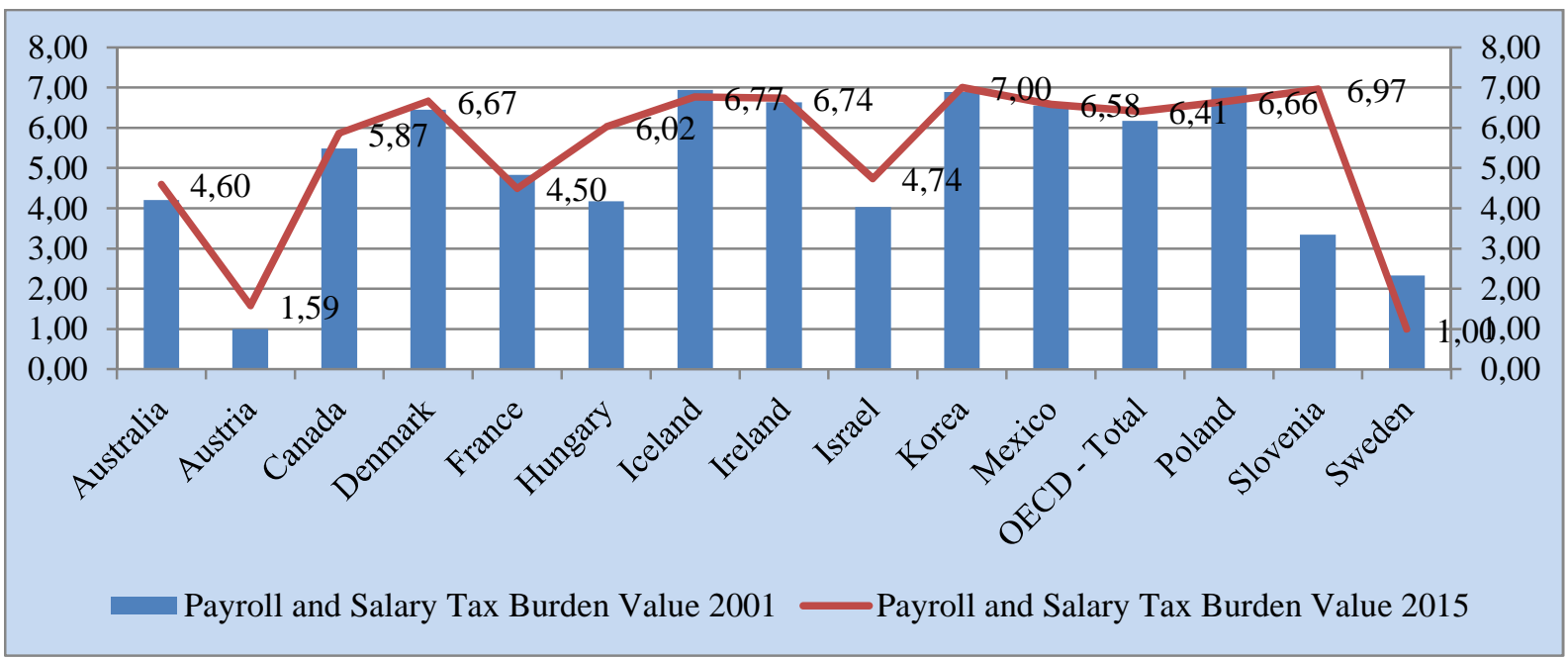

Source: (OECD Revenue Statistic, http://www.oecd-ilibrary.org/taxation/data/revenuestatistics/comparative-tables_data-00262-en, 09.09.2017)

In the Graph (5),for payroll and wage taxes, in 4 among 15 countries - France, Iceland, Poland and Switzerland - tax burden had decreased between the years 2001 and 2015. Sweden became the least burdened country. OECD average decreased 4 points. 


\section{Graph 6.Social Insurance Contributions Burden Value Changing From 2001 to 2015}

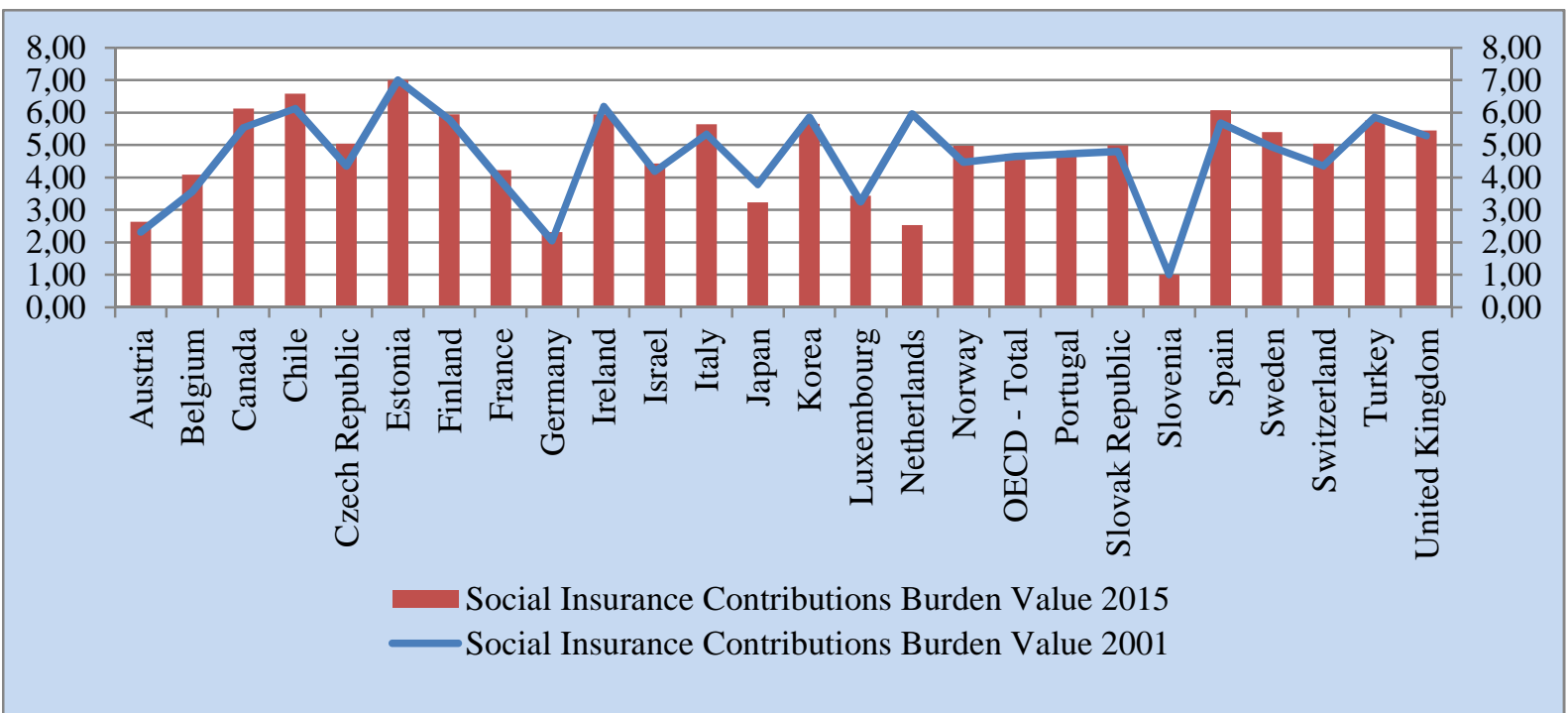

Source:(OECD Revenue Statistic, http://www.oecd-ilibrary.org/taxation/data/revenuestatistics/comparative-tables_data-00262-en, 09.09.2017)

For SSC's, Graph(6), in 6 among 26 countries - Ireland, Japan, S. Korea, Netherlands, Portugal and Turkey - burden of these contributions had decreased. In Netherlands this decrease was nearly $60 \%$.OECD average has increased $2 \%$ in this 10 -year period. For both perceived as an important cost element in labour employment and accepted as a determinant of international investment competition, decrease in SSC burden is an important tax policy tool.But few countries could have decreased their burdens. This means, SSC is still having a social importance.Besides direct regulations, decrease of SSC burden in Turkey can be explained by unemployment (10,2\% for 2017 May) and unregistered employment $(34,2 \%$ for 2017 May).

Graph 7.Income and Profit Tax Burden Value Changing From 2001 to 2015

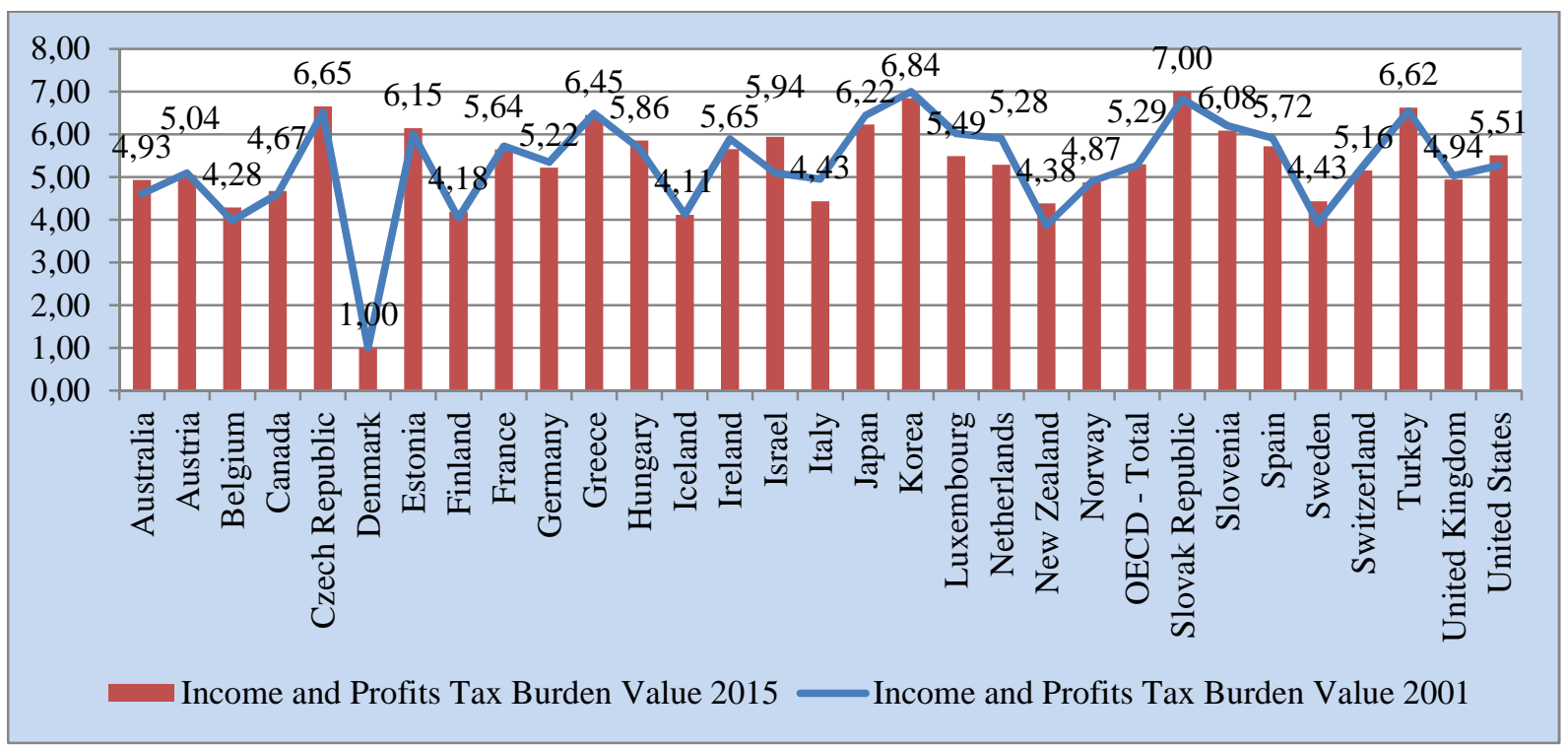

Source:(OECD Revenue Statistic, http://www.oecd-ilibrary.org/taxation/data/revenuestatistics/comparative-tables_data-00262-en, 09.09.2017) 


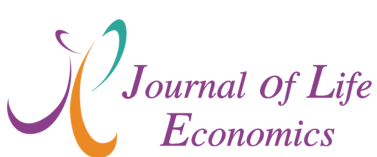

Graph (7) shows the tax burden on income and profits. About half of the 31 countries tax burden had decreased.Countries with highest decrease values are: Italy, Netherlands and Luxemburg.Tax burden decrease can be explained as a case of a perception in which high income groups are considered to have a saving potential.But, as predominant ratio of public revenues comes from taxation of these sources, large tax burden decreases are not being seen.

\section{Graph 8. Growth Rate of Individual Income Taxation \& Gross National Savings Correlation (2000-2015)}

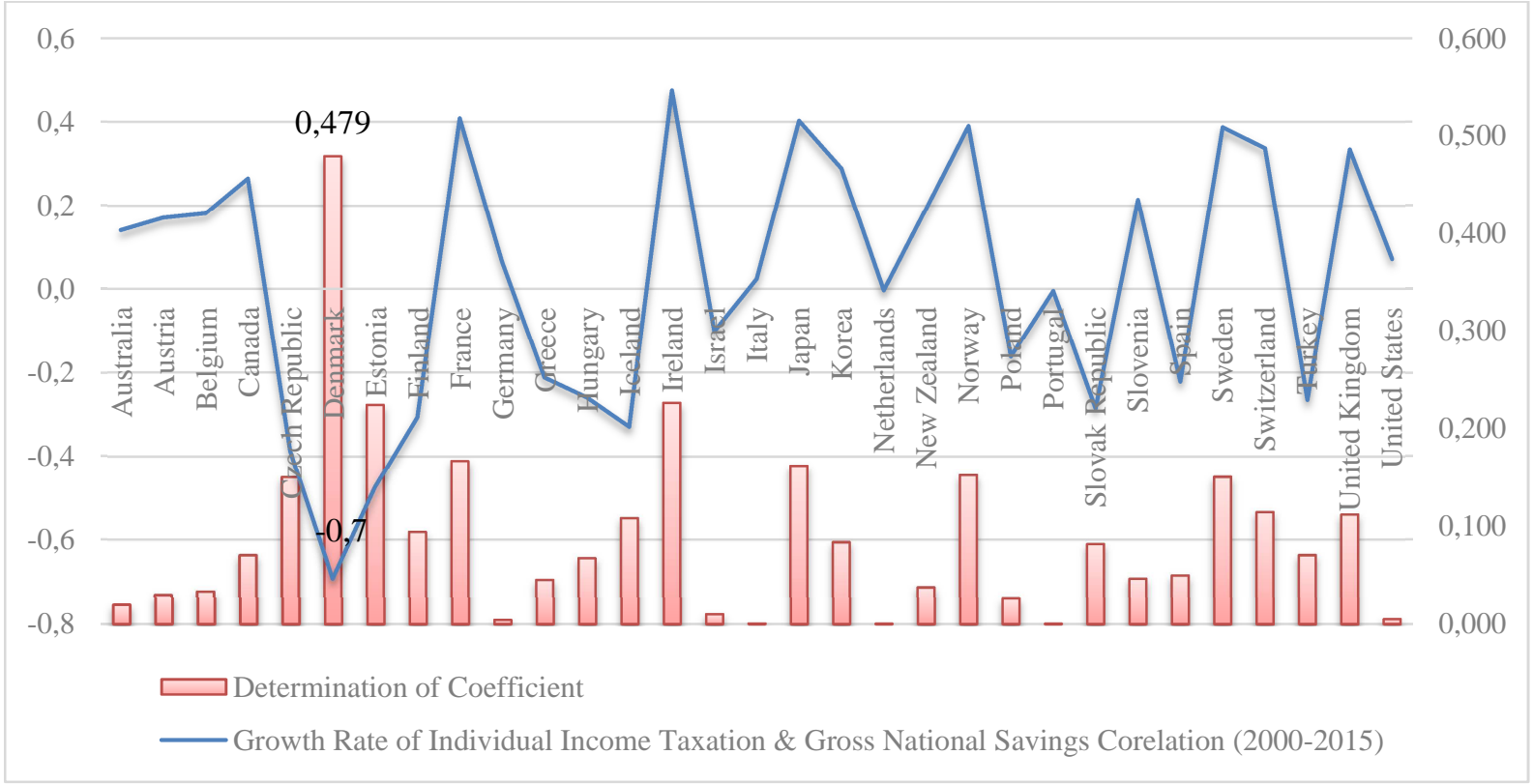

Source:(OECD Revenue Statistic, http://www.oecd-ilibrary.org/taxation/data/revenuestatistics/comparative-tables_data-00262-en, 09.09.2017)

The Graph (8) shows the relation between PIT (except for payroll and salary taxes) and changes in level of savings. An increase in PIT gives rise to an expectation of a fall in saving levels. But country comparisons have given no precise results.Among the 31 countries, 12 of them have shown a negative correlation.

\section{Graph 9. Growth Rate of Corporate Income Taxation \& Gross National Savings} Correlation (2000-2015)

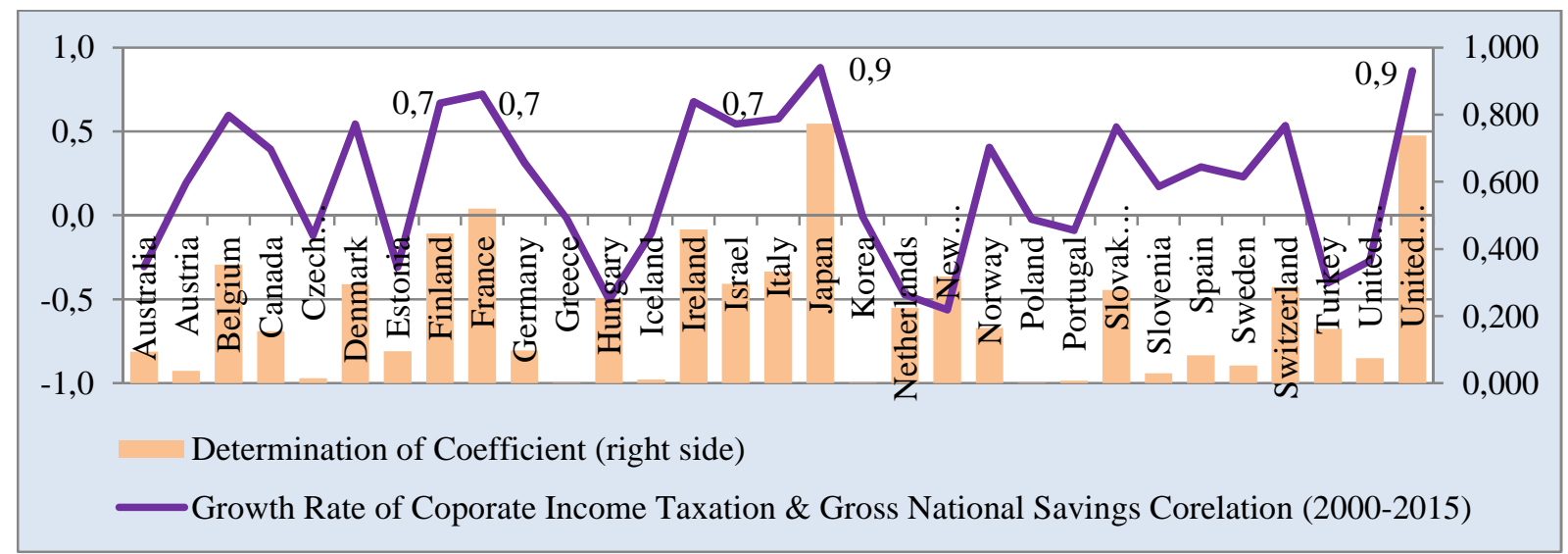

Source:(OECD Revenue Statistic, http://www.oecd-ilibrary.org/taxation/data/revenuestatistics/comparative-tables_data-00262-en, 09.09.2017) 


\section{$\int\left(\begin{array}{c}\text { Journal of Life } \\ \text { Economics }\end{array}\right.$}

The Graph (9) shows the relation between company income taxation (CIT) and total savings. This relationship has been lower than achieved in practice for income tax. In 10 of the 31 countries results are negative.

Graph 10.Goods and Services Tax Burden Value Changing From 2001 to 2015

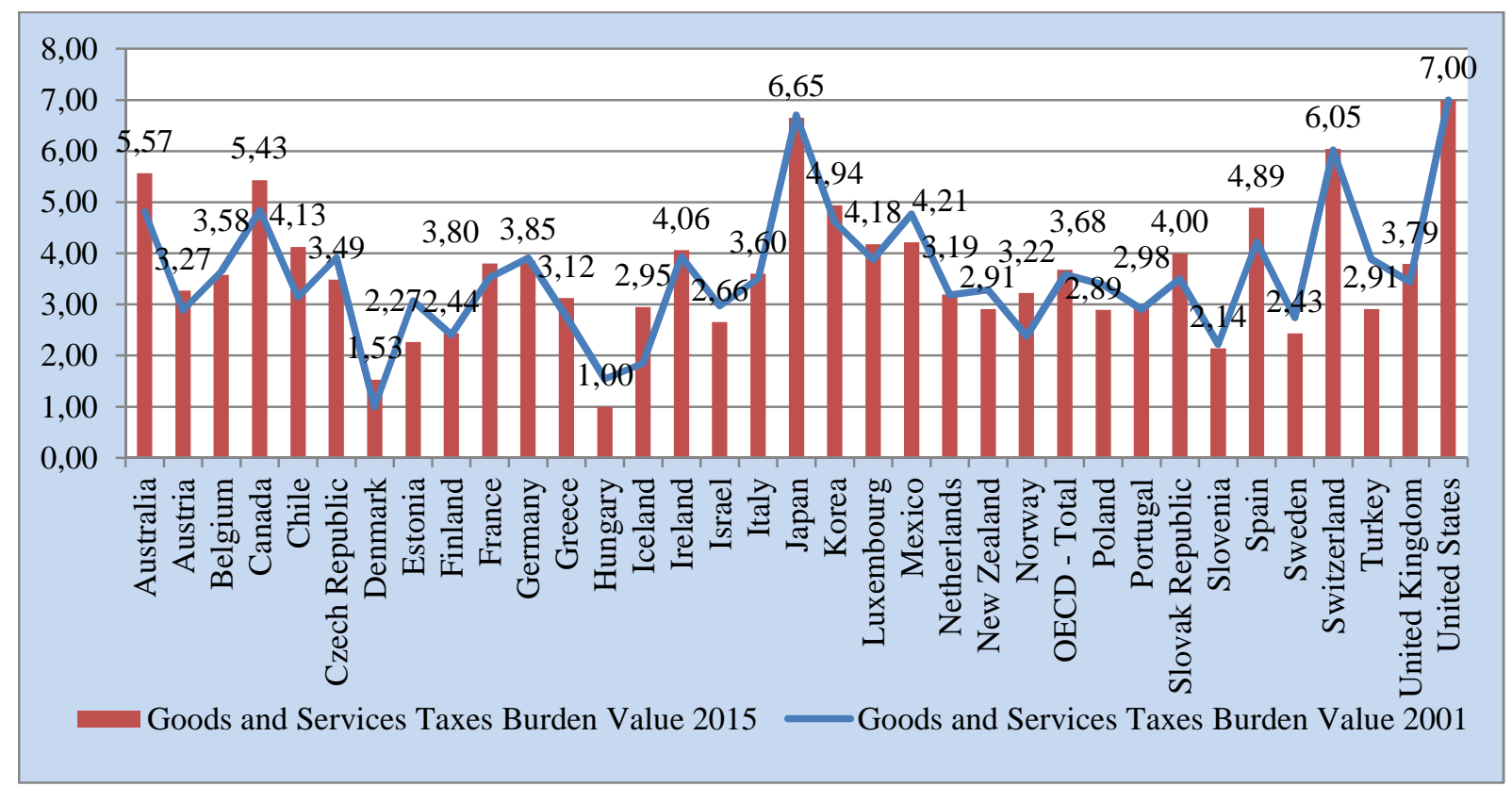

Source:(OECD Revenue Statistic, http://www.oecd-ilibrary.org/taxation/data/revenuestatistics/comparative-tables_data-00262-en, 09.09.2017)

Graph (10) shows that there occurred a decrease in consumption taxes burden in 13 of the 35 countries. Estonia, Hungary and Turkey are the most significant ones. But consumption taxes have a highest proportion in these 3 countries.Onaranet. al. (2010) which takes EU - 15 into account, indicates that, the fact of globalization does not have an incremental effect on consumption taxes (Onaran et. al., 2010: 14 and 18). As a result of not taking into account of tax payers personal situations (economic and/or social), these taxes have a negative impact on income distribution and poverty.In Itriago (2011) it is mentioned that tax exemptions on goods and services mainly used by the poorest maydecrease the level of regressivity of indirect taxes, but still being implemented those incentivesor exemptions for companies and the richest people, raises suspicious about the fairness of these tax systems (Itriago, 2011: 4445).There is a similar remark in Gemmel and Morrisey (2002). They indicate, when these taxes are not put into practice, it will be efficient for the fight against poverty (Gemmel and Morrisey, 2002: 64 and 66). 
Graph 11.Corporate Income Tax Burden Value Changing From 2001 to 2015

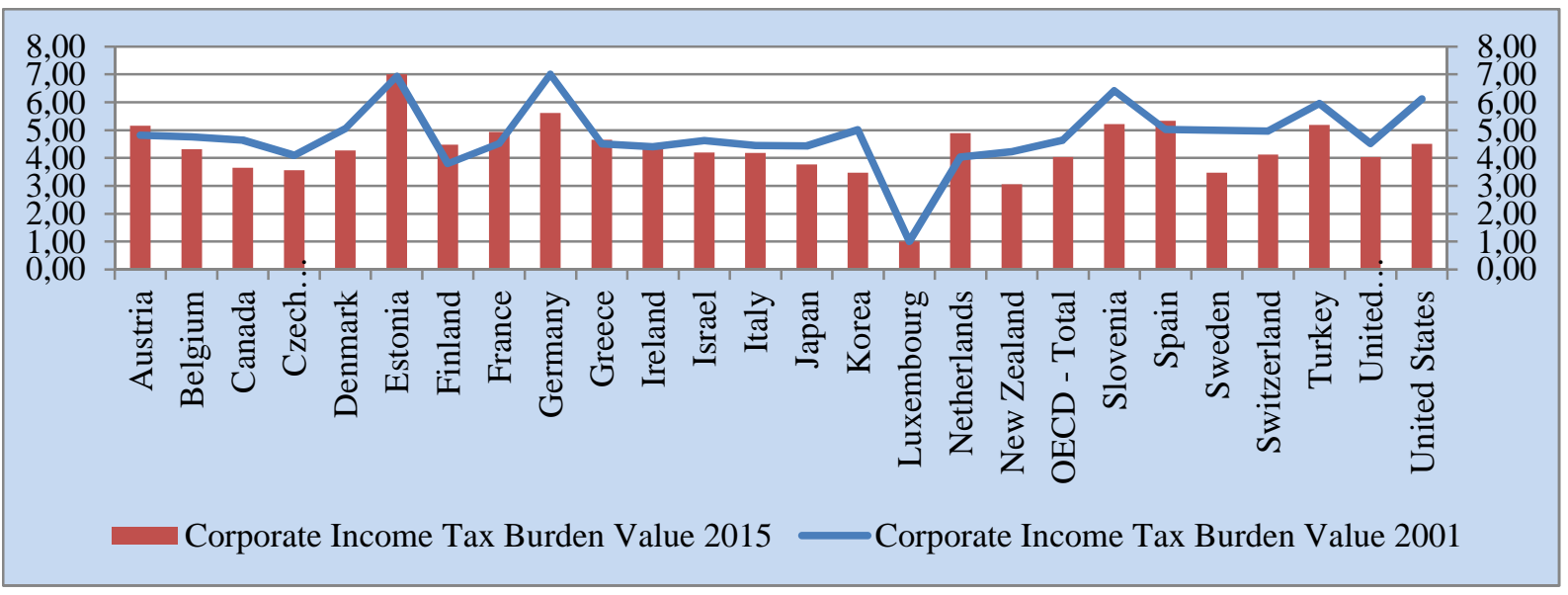

Source:(OECD Revenue Statistic, http://www.oecd-ilibrary.org/taxation/data/revenuestatistics/comparative-tables_data-00262-en, 09.09.2017)

Graph (11) shows the distribution and change in corporate profit taxation between the years 2001 and 2015. Tax burden reductions can be seen in 9 of the 26 countries in this period. OECD average has also decreased by 13\%.In Itriago (2011), it is said that taxes levied on business activity have been in decline especially in spite of the recent global economic crisis throughout the world (Itriago, 2011: 6). In OECD developing countries,applications of exemptions and deductions lead to reduce the business tax base effectively. Whenever there is a crisis or when the underdeveloped or developing countries need to adapt to the system, regulatory reforms are on the agenda. In reform regulations it is stated that tax revenue increases will be provided by persons who are required to pay tax (according to the ability to pay criterion) and thereby reducing the inequality of the reform, but there is no indication that the burden on the low-income class has diminished in the studies carried out. (Fjeldstad and Moore, 2008: 244). In Tanzi (1980), erosion index gives high results for developing countries and this indicates a negative situation in terms of justice issues.

Graph 12.Property Tax Burden Value Changing From 2001 to 2015

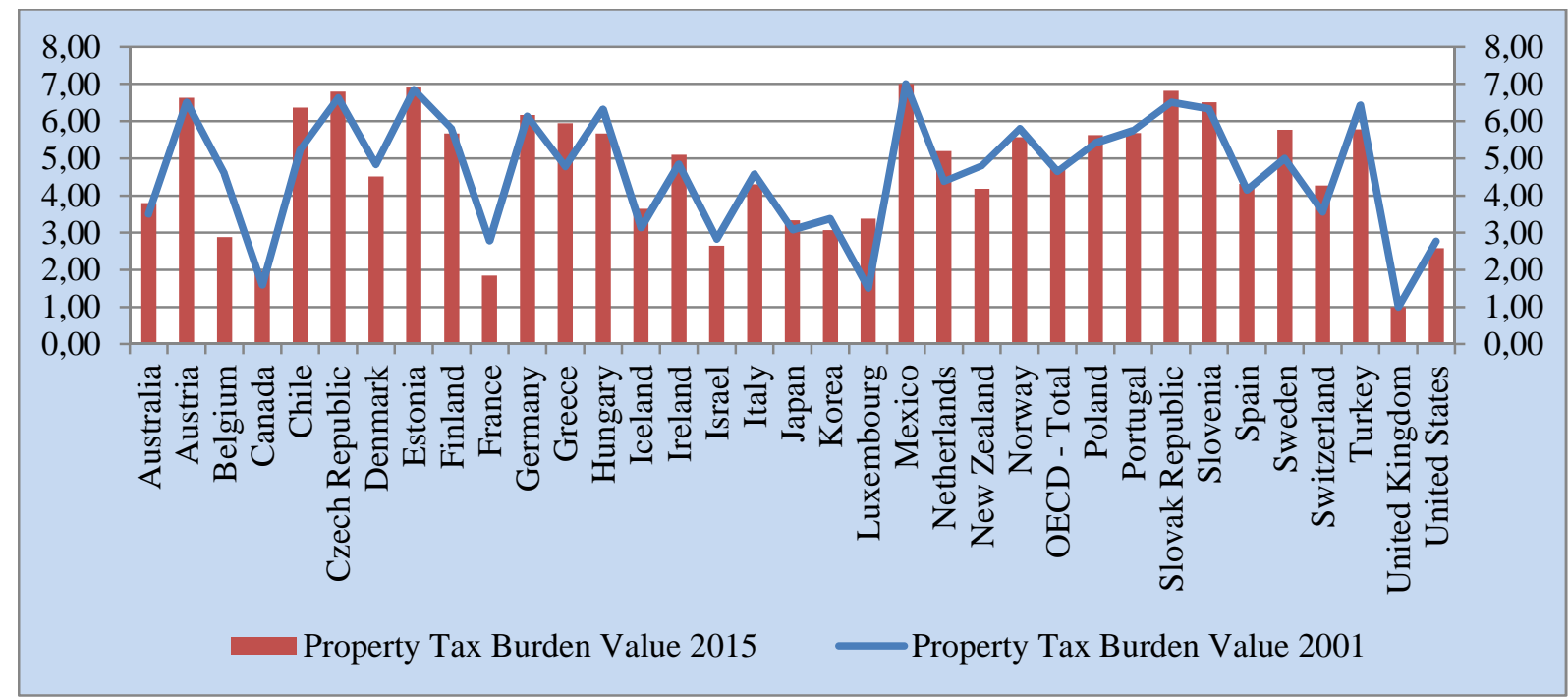

Source:(OECD Revenue Statistic, http://www.oecd-ilibrary.org/taxation/data/revenuestatistics/comparative-tables_data-00262-en, 09.09.2017) 
Comparing the period between 2001 and 2015, Graph (12) shows a decrease in property taxes in 13 countries.Bryset. al.(2011) and Joumardet. al. (2012) indicates that, with consumption taxes, taxes on property have the less distorting and growth oriented taxes but which are less effective in income distribution issues because of their flat rated structure (Brys et al. 2011: 16; Joumard et al. 2012: 18).

Graph (13) shows the effects of tax burden on production factors and total burden. Countries which increase the value of index by means of an increase in labour income tax burden are: Canada, Denmark, France, Iceland, Ireland, Israel, S. Korea, Mexico, Poland and Portugal. In remaining 25 countries' total tax burden could have been affected by other factors, most dominantly like as income and profit taxes. It is stated that taxation is more related to capital elements in welfare state structuring, but with the "globalization" process both the end of the welfare state approach and the opening of international markets are directed towards labor force elements (Kemmerling, 2009: 75). Bird (2010) indicates that, capital taxes are not preferred recently, because of efficiency, competition, political coherence and international investment competition considerations (Bird, 2010: 1-2). Naturally, governments have to close this revenue gap with several ways. Information on national and international tax practices show that the tax burden on the profit is reduced, the income gap is covered by wage taxation and therefore the problems of distribution continue. (Caskurlu, 2011: 210).

\section{Graph 13.The Effects of Tax Burden on Production Factors and Total Burden}

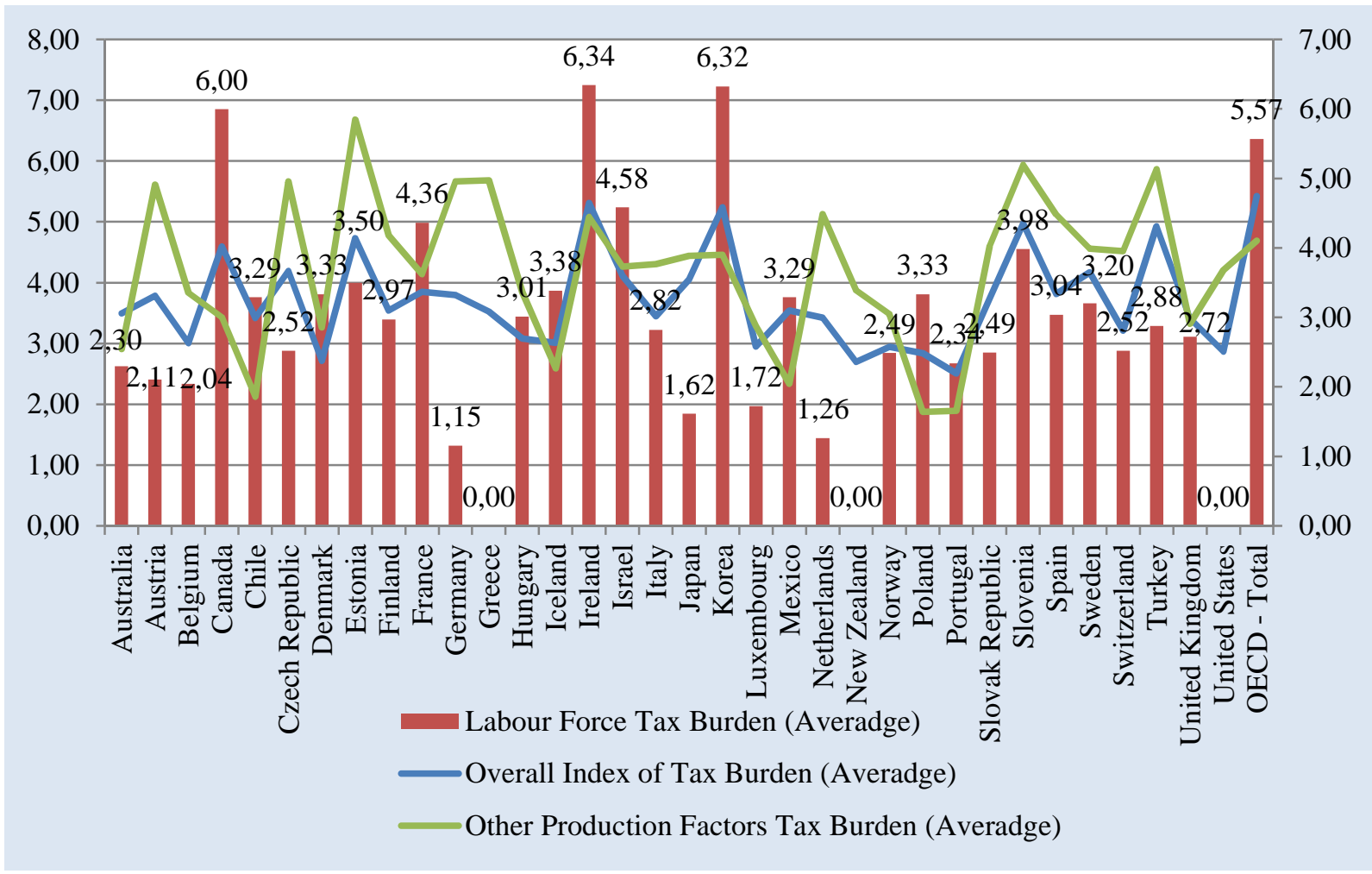

Source:(OECD Revenue Statistic, http://www.oecd-ilibrary.org/taxation/data/revenuestatistics/comparative-tables_data-00262-en, 09.09.2017)

From different point of view, it can be analyzed the tax pressure on production factors. In this study by using Oyan (1998)'s methodology for calculation of labour and capital factors' tax pressure. In this calculation it is used two different kinds of formula which include shares of taxes and features of GDP. OECD countries' tax burdens will be calculated in years between 2007 and 2015. Formulas are below. 


\begin{tabular}{|c|c|}
\hline $\begin{array}{c}\text { Factor of Labour } \\
\text { Tax Burden(2) }\end{array}$ & $\begin{array}{c}\text { Payroll and Wage Tax }+ \text { SSC/Total Tax Revenue } \\
\text { Compensation of Employees/GDP(income approach) }\end{array}$ \\
\hline $\begin{array}{c}\text { Factor of Capital } \\
\text { Tax Burden(3) }\end{array}$ & Income - Profits - Capital Taxes/Total Tax Revenue \\
\hline
\end{tabular}

According to this calculation, a tax pressure on labour factor can be seen in Austria $(83 \%-73 \%)$, France $(78 \%$ - 67\%), Hungary (74\% - 57\%), Slovenia (78\% - 59\%), Mexico $(57 \%-44 \%)$ and Turkey $(39 \%-24 \%)$. Relocation of the tax burden to sources with the lowest tax avoidance capacity is based on the assumption that taxation of the workforce is economically and politically more effective when the capital is highly flexible because shifting the tax base to the capital is a very difficult undertaking for politicians (Kemmerling, 2009: 36).

Graph 14.The Calculation of the TaxPressure on LabourFactor (2011 - 2015)

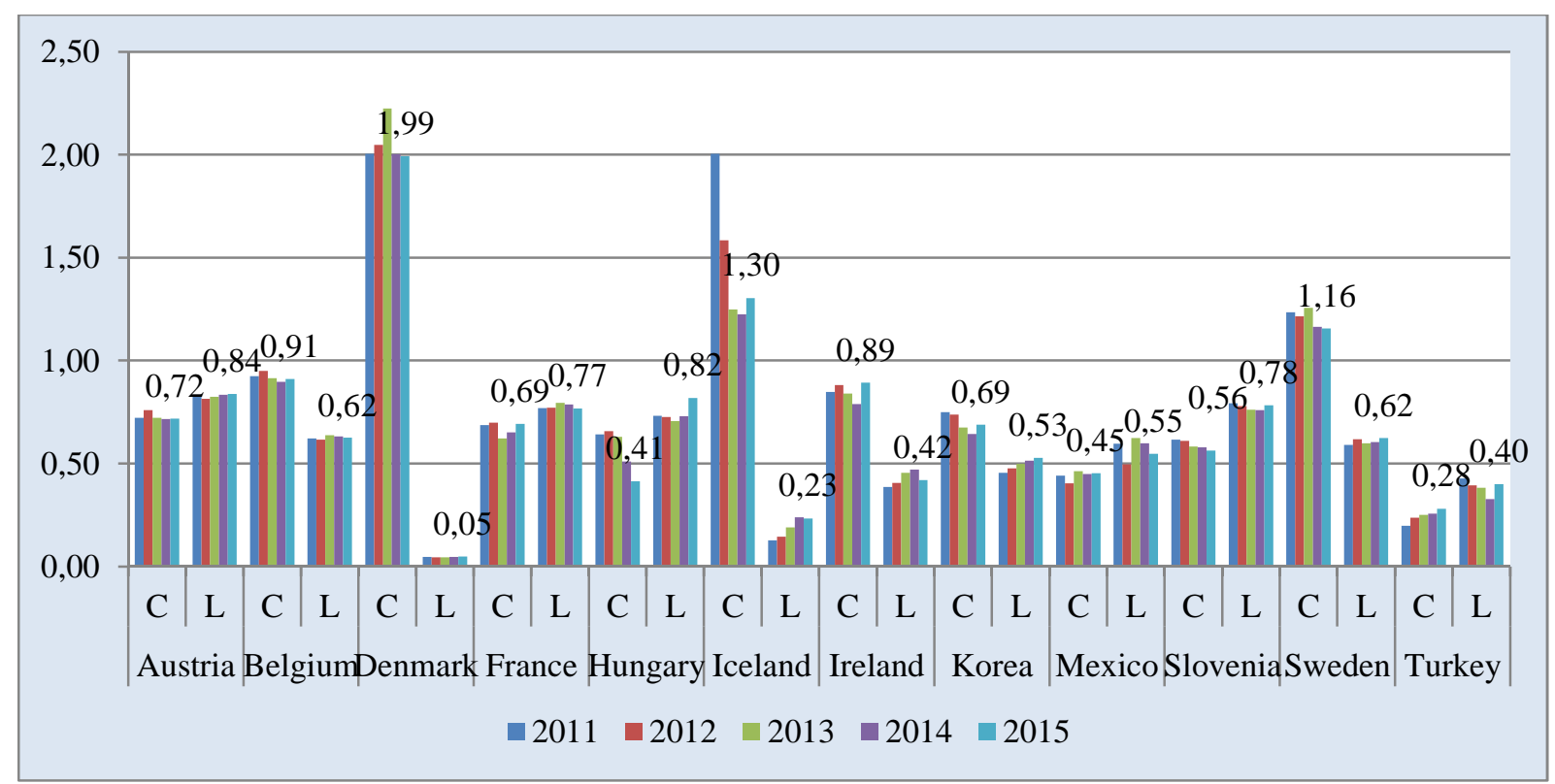

Source:(Own calculation from the data in OECD, National Account Series, Labor Statistics)

It is possible to examine tax burdens of production factors in terms of different tax ratios. Especially it has to be needed to examine the ratios of different kind of taxes. 


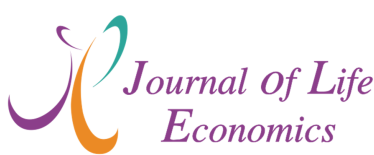

\section{Graph 15.VAT - Individual and Corporate Max Tax Rate (2017)}

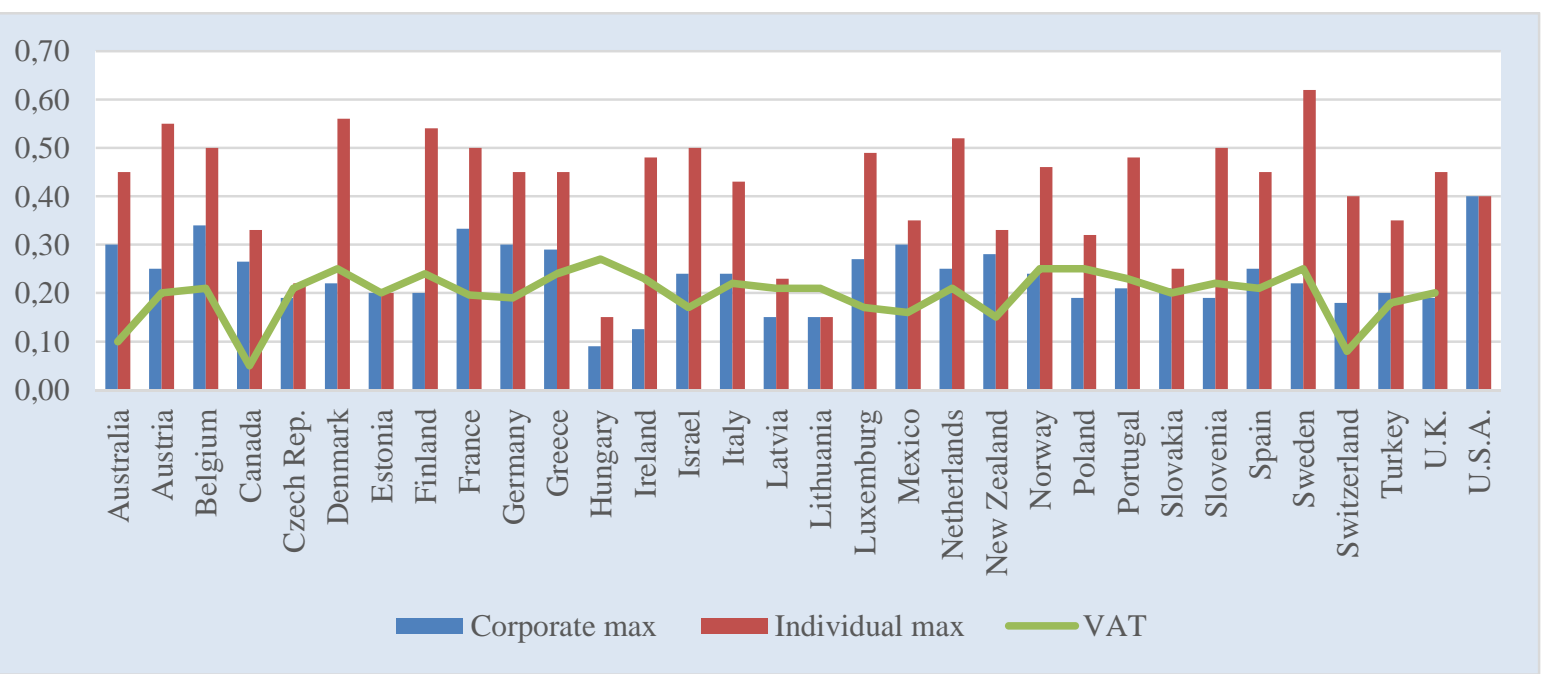

Source: KPMG, Tax Tools and Resources, 2017,https://home.kpmg.com/xx/en/home/services/tax/taxtools-and-resources/tax-rates-online/individual-income-tax-rates-

table.html;https://home.kpmg.com/xx/en/home/services/tax/tax-tools-and resources/tax-ratesonline/corporate-tax-rates-table.html; https://home.kpmg.com/xx/en/home/services/tax/tax-tools-andresources/tax-rates-online/indirect-tax-rates-table.html, (07.10.2017)

As can be seen in the Graph (15), in Switzerland, Czech Republic, Slovakia and Hungary, PIT rate is higher than CIT rate. In Estonia, Lithuania and USA, highest marginal rates are equal. A highest disparity in income tax rates is in Sweden.

\section{Graph 16. Top Marginal Income Tax Rate - Top Statuary Corporate Tax Rate (2017)}

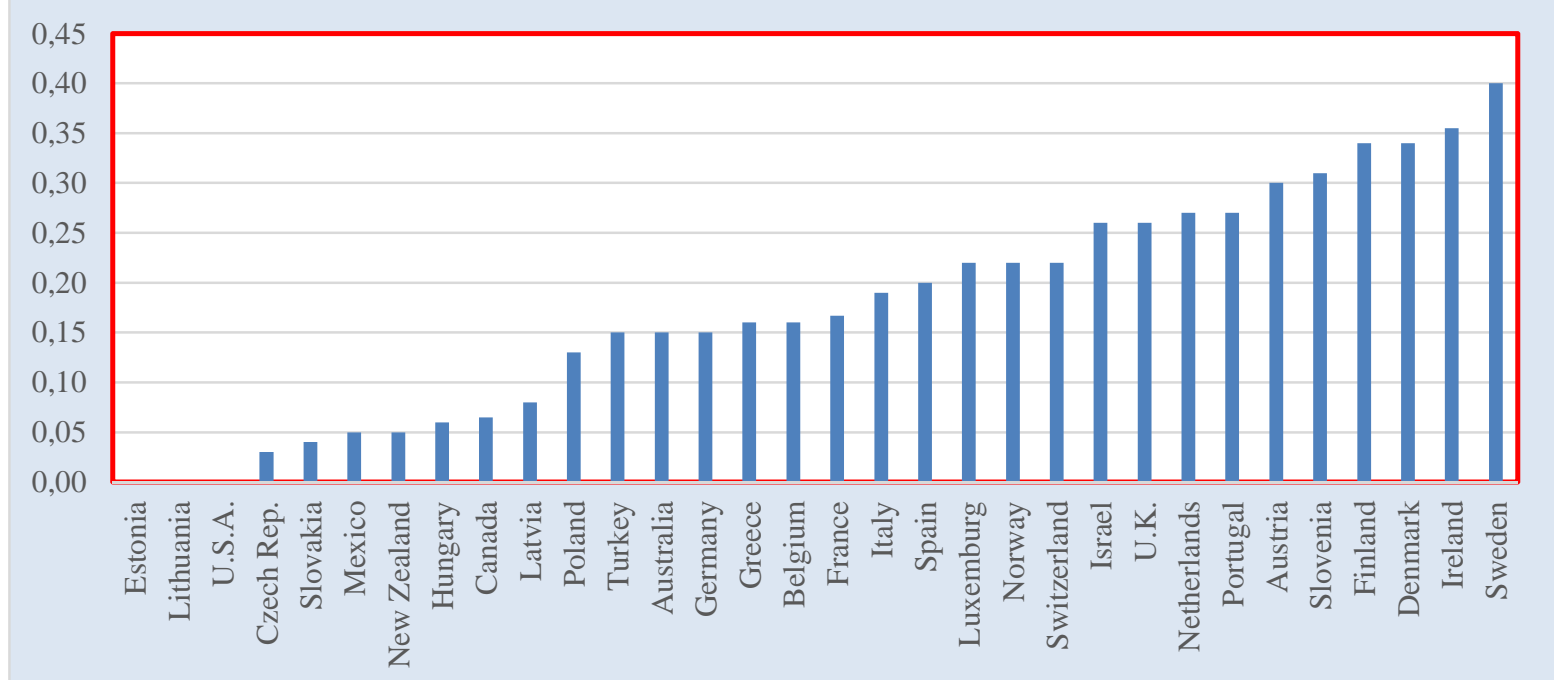

Source: KPMG, Tax Tools and Resources, 2017,https://home.kpmg.com/xx/en/home/services/tax/taxtools-and-resources/tax-rates-online/individual-income-tax-rates-

table.html;https://home.kpmg.com/xx/en/home/services/tax/tax-tools-and resources/tax-ratesonline/corporate-tax-rates-table.html; https://home.kpmg.com/xx/en/home/services/tax/tax-tools-andresources/tax-rates-online/indirect-tax-rates-table.html, (07.10.2017)

Analysis of taxes in 2016, a trend of top marginal tax rates of company income is shown in the Graph (16)has still continued under the income tax rates. 


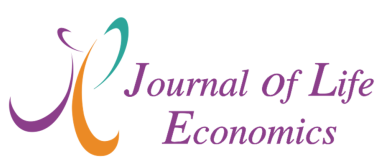

\section{THE SPECIFIC USE OF TAXATION FOR POVERTY REDUCTION}

When income is taxed by governments by different rate and forms, income differences become clearer.In designing tax systems, it is essential for governments to take, income inequalities, absence of income, absence of wealth and basically poverty issues into account.

\subsection{In the Context of International Politic Economy Determination of Poverty and Relations with the Taxation}

In Aktan and Vural (2002), poverty is expressed as the inability to reach sources and production factors due to financial inadequacies, and the absence of a minimum level of income to survival (Aktan and Vural, 2002: 3). In terms of objective measurement of poverty there are two determinations called poverty line and poverty gap. Poverty line is expressed an income level (quoted from Erdem, (2006) Aksan, 2012:12), which is below an income level that does not allow people to obtain their basic needs. But singly it may not be able to indicate the exact distinction between a poor and poorer (Uzun, 2003: 156). So, associated with the concept of poverty line, it is defined an additional concept name poverty gap. The poverty gap is the sum of the difference between the poverty line and the actual income levels of all people living under this border (Uzun, 2003: 157). Besides that,in an economy distribution of income is represented by a Lorenz Curve and the degree of income inequality is measured via the Gini Coefficient (Agarwal, 2017).

The poverty line, poverty gap and Gini coefficient can be exploited to explain the income inequalities and poverty between the countries.

\section{Graph 17.Gini Coefficent for Some OECD Countries (2014)}

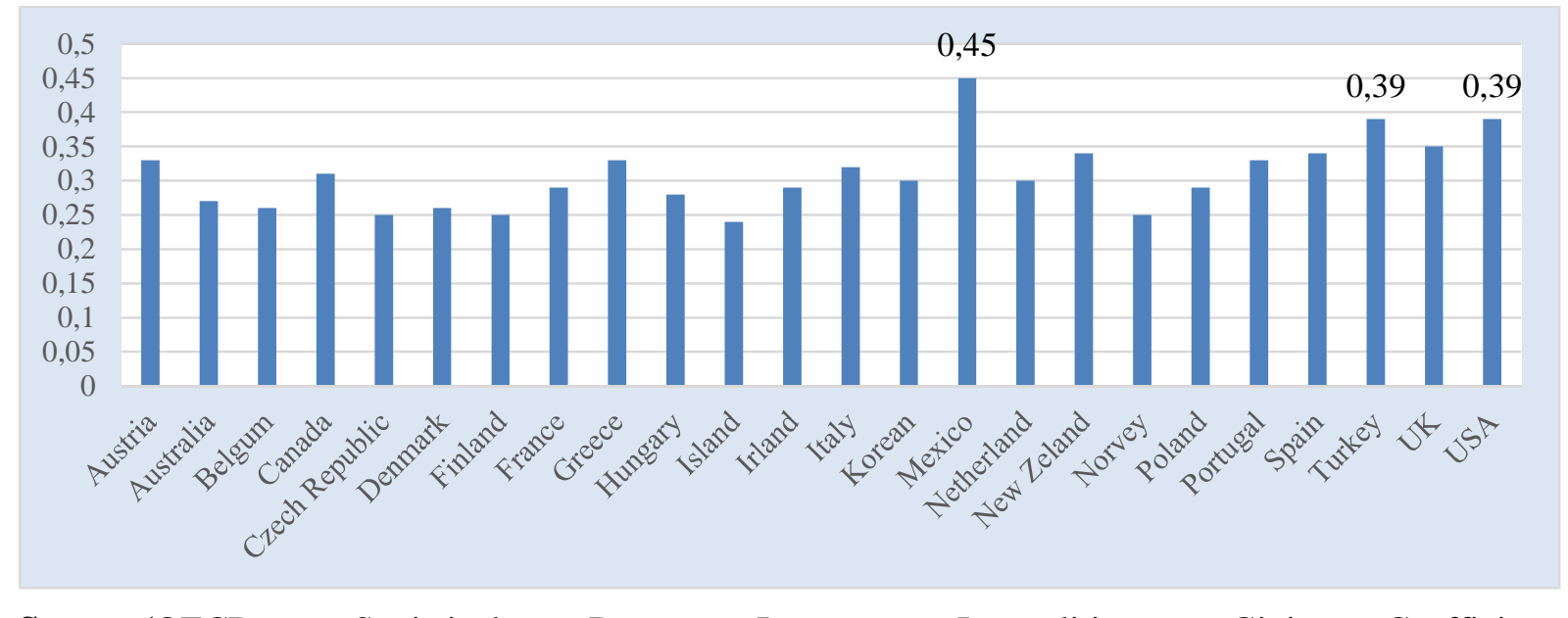

Source:(OECD, Statistical Data, Income Inequalities, Gini Coefficient, https://data.oecd.org/inequality/income-inequality.htm, 05.09.2017)

Graph (17) shows high valued countries are Mexico, Turkey and US for Gini coefficient. Besides Gini calculation, below there is a graphic shows a relation between two important indication names are poverty line and poverty gap. 


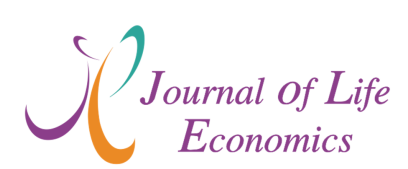

Graph 18.Poverty Line and Poverty Gap for Some OECD Countries (2014)

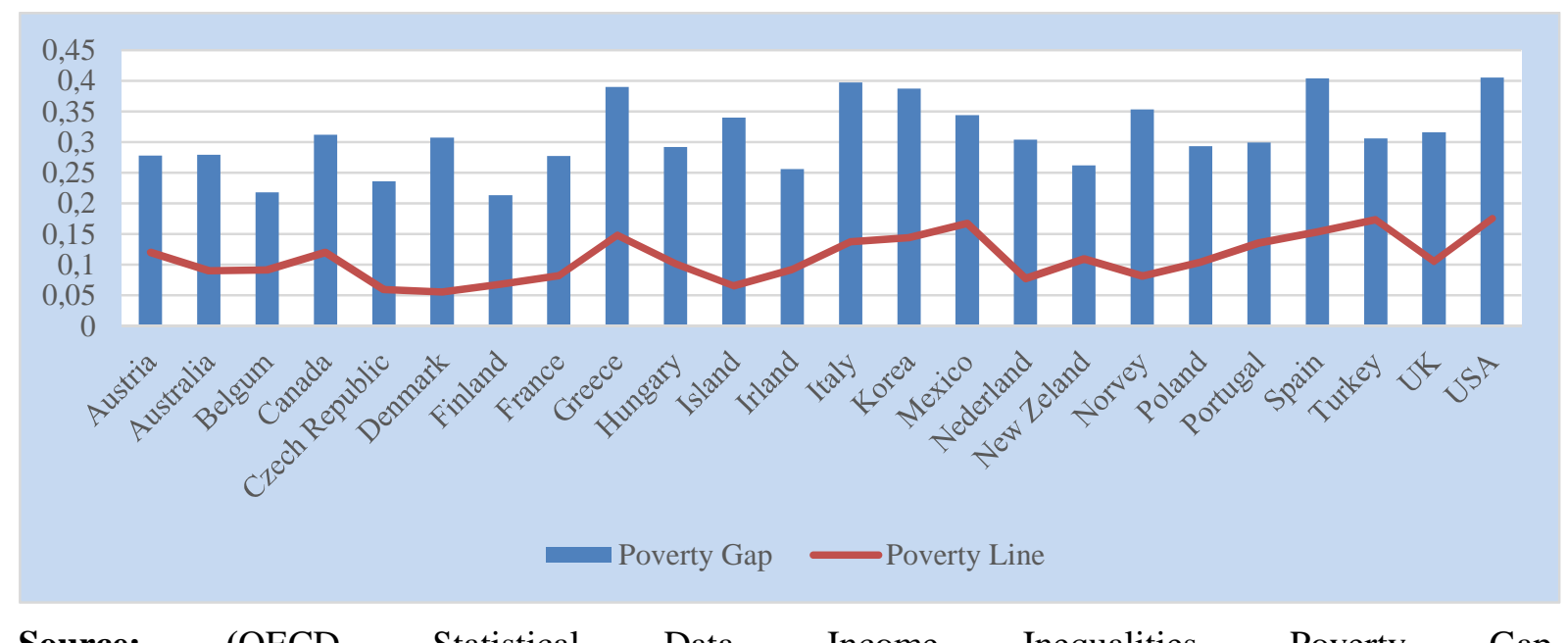

Source: (OECD, Statistical Data, Income Inequalities, Poverty Gap, https://data.oecd.org/inequality/poverty-gap.htm, 05.09.2017)

Graph (18) shows the relation between poverty line and gap in some OECD countries. So, the distance from the top of the bar graphic in blue and the line graphic in red, indicates the range between the poor and poorer for a given country. The more distance between them, the greater the number of poor people. Moving from the data, the following results have been achieved.The countries such as; Greece, Spain and USA have a high Gini coefficient also both have high poverty gaps. Besides that, Italy and Korea are high marked poverty gap countries. Turkey is $13^{\text {th }}$ country for poverty gap ratio in the group of overall 24 countries.

\subsubsection{Family Taxation and Poverty Interaction}

Especially when regulating PIT, economic and social conditions are being taken into account. In this respect, the fact of "family" has an importance. Taxation especially income taxation may affect after tax earnings of family members. Moreover,any economic decision would be affected adversely by taxation in a family scale. In those kinds of situations, problems may vary between earnings, wealth, poverty, employment etc. For example, in Schwarz 2012 it is stated that female employment is affected negatively by tax distortions towards married families (Schwarz, 2012: 26). 


\section{Graph 19. A Change in Net Income after Taxes $2004-2016$} (in US dollars using PPP exchange rates)

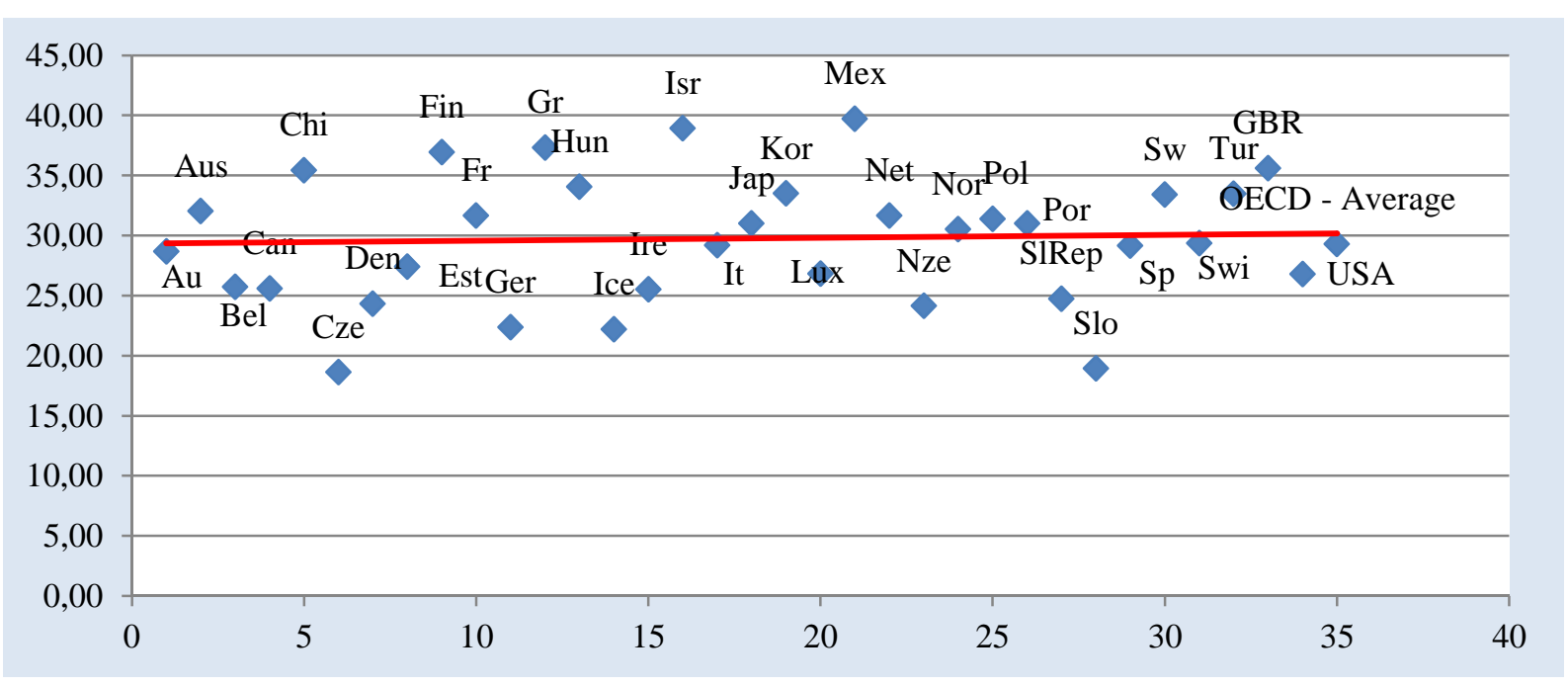

Source:(OECD Taxing Wage Statistics, http://www.oecd-ilibrary.org/taxation/data/taxingwages/comparative-tables_data-00265-en, 01.09.2017)

Note:Advanced Economies:Australia, Austria, Belgium, Canada, Cyprus, Czech Republic, Denmark, Estonia, Finland, France, Germany, Greece, Hong Kong SAR, Iceland, Ireland, Israel, Italy, Japan, Korea, Luxembourg, Malta, Netherlands, New Zealand, Norway, Portugal, San Marino, Singapore, Slovak Republic, Slovenia, Spain, Sweden, Switzerland, Taiwan Province of China, United Kingdom, and United States.

Differences in net income after taxes (in US dollar PPP) are indicated in the Graph (19).In this analysis it is made comparison between one-earner and two earner married couple (one at $100 \%$ of average earnings and the other at $33 \%$ ).OECD average is approximately $30 \%$. In other words, when a family's income level increases, tax income increases 3 to 1 proportion in comparison with the other group after. Examining the countries that are above the average, it can be seen that in previous period's poverty rates, poverty gap or both were not taken into account when relation between income differences and poverty issues were considered in taxation. These countries are Norway, Portugal, Japan, Poland, France, Switzerland, S. Korea, Hungary, Chile, UK and Mexico. Especially in Mexico, S. Korea, Norway and UK, which have the highest poverty gaps, taxation of low income groupshas increased marginal tax burden.

\subsubsection{Progressive Taxation and Poverty Interaction}

Considering the relation between impoverishment and social justice in taxation, progressive taxation must be taken into account. In progressive taxes, average rate increases with the income level and marginal rate increases more than average rate. Progressivity indicates an increase in tax burden, when income levels change. According to Edizdogan and Çelikkaya (2010), progressivity raises from the relation between average and marginal tax rates (Edizdoğan and Çelikkaya, 2010: 35). In other words, in progressive taxes, average rate increases with the income level and marginal rate increases more than average rate.

Average rate $=[\mathrm{Tp} / \mathrm{Tb}](4)$

Marginal rate $=\left[\left(\mathbf{T p}^{2}-\mathbf{T} \mathbf{p}^{1}\right) /\left(\mathbf{T b}^{2}-\mathbf{T} \mathbf{b}^{1}\right)\right](5) \ldots \ldots \ldots \ldots . . .$. Tp: Payed tax, Tb: Tax base $(\mathbf{2})$

In taxation, average rate reflects that how much amount of taxes must be paid additionally while the tax base is rising. So, rising of average rates coincide with increased progressivity. Besides that, marginal tax rate reflects that how effects a percent increase of 
income on taxes payable. While the marginal tax rate increases, income from additional work decreases.So, marginal tax rates determine the size of the incentive to work (leisure time attractiveness) (Edizdoğan and Çelikkaya, 2010: 35).

In Table 1, there is an original contribution that it is calculated the average and marginal tax rates in many OECD countries by using their own tax tariffs and different annual income levels scenarios. Incomes which base of calculating the tax liabilities are expressed in US dollars using PPP exchange rates. This gives opportunities to evaluate the changes between different countries.

Table 1. Individual Income Tax Applications in Different OECD Countries by Using Different Annual Income Levels Scenarios (in US dollars using PPP exchange rates for incomes)

\begin{tabular}{|c|c|c|c|c|c|c|c|}
\hline & $\begin{array}{l}\text { Lower Limits } \\
\text { of Income }\end{array}$ & $\begin{array}{l}\text { Upper } \\
\text { Limits of } \\
\text { Income }\end{array}$ & $\begin{array}{c}\text { Tax Rate } \\
(\%)\end{array}$ & $\begin{array}{c}\text { Scenarios: } \\
\text { Amounts of } \\
\text { Annual } \\
\text { Incoime } \\
6000,18000, \\
66000, \\
150000 \$\end{array}$ & $\begin{array}{c}\text { Total Tax } \\
\text { Amount }\end{array}$ & $\begin{array}{l}\text { Average } \\
\text { Tax Rate }\end{array}$ & $\begin{array}{l}\text { Marginal } \\
\text { Tax Rate }\end{array}$ \\
\hline \multirow{4}{*}{ Austria } & 1 & 16675 & 0 & 6000 & 0 & 0.00 & 0.00 \\
\hline & 16677 & 37898 & 0.365 & 18000 & 6570 & 0.37 & 0.55 \\
\hline & 37899 & 90955 & 0.432 & 66000 & 28512 & 0.43 & 0.46 \\
\hline & 90956 & $\ldots$ & 0.5 & 150000 & 75000 & 0.50 & 0.55 \\
\hline \multirow{5}{*}{ French } & 1 & 8787 & 0 & 6000 & 0 & 0.00 & 0.00 \\
\hline & 8788 & 17530 & 0.055 & 18000 & 2520 & 0.14 & 0.21 \\
\hline & 17531 & 38932 & 0.14 & 66000 & 19800 & 0.30 & 0.36 \\
\hline & 38934 & 104373 & 0.3 & 150000 & 61500 & 0.41 & 0.50 \\
\hline & 104375 & $\ldots$ & 0.41 & & & & \\
\hline \multirow{4}{*}{ Canada } & 1 & 35299 & 0.15 & 6000 & 900 & 0.15 & 0.15 \\
\hline & 35300 & 70599 & 0.22 & 18000 & 2700 & 0.15 & 0.15 \\
\hline & 70600 & 109439 & 0.26 & 66000 & 14520 & 0.22 & 0.25 \\
\hline & 109440 & $\ldots$ & 0.29 & 150000 & 43500 & 0.29 & 0.35 \\
\hline \multirow{4}{*}{ Poland } & 0 & 13800 & 0.18 & 6000 & 1080 & 0.18 & 0.18 \\
\hline & 13800 & $\ldots$ & 0.32 & 18000 & 5760 & 0.32 & 0.39 \\
\hline & & & & 66000 & 21120 & 0.32 & 0.32 \\
\hline & & & & 150000 & 48000 & 0.32 & 0.32 \\
\hline \multirow{8}{*}{ Portugal } & 1 & 9799 & 0.115 & 6000 & 690 & 0.12 & 0.12 \\
\hline & 9801 & 14825 & 0.14 & & & & \\
\hline & 14827 & 36762 & 0.245 & 18000 & 4410 & 0.25 & 0.31 \\
\hline & 36764 & 84545 & 0.355 & & & & \\
\hline & 84547 & 122528 & 0.38 & 66000 & 23430 & 0.36 & 0.40 \\
\hline & 122530 & 132133 & 0.415 & & & & \\
\hline & 132135 & 306099 & 0.435 & 150000 & 65250 & 0.44 & 0.50 \\
\hline & 306101 & $\ldots$ & 0.465 & & & & \\
\hline \multirow{2}{*}{ Italy } & 0 & 24333 & 0.23 & 6000 & 1380 & 0.23 & 0.23 \\
\hline & 24334 & 45421 & 0.27 & 18000 & 4140 & 0.23 & 0.23 \\
\hline
\end{tabular}




\begin{tabular}{|c|c|c|c|c|c|c|c|}
\hline & 45422 & 89220 & 0.38 & 66000 & 17820 & 0.27 & 0.29 \\
\hline & 89221 & 121663 & 0.41 & 150000 & 64500 & 0.43 & 0.56 \\
\hline & 121665 & $\ldots$ & 0.43 & & & & \\
\hline \multirow{5}{*}{ Germany } & & & & & & & \\
\hline & 0 & 13047 & 0 & 6000 & 0 & 0.00 & 0.00 \\
\hline & 13048 & 84862 & 0.14 & 18000 & 2520 & 0.14 & 0.21 \\
\hline & 84864 & 402365 & 0.42 & 66000 & 9240 & 0.14 & 0.14 \\
\hline & 402367 & $\ldots$ & 0.45 & 150000 & 63000 & 0.42 & 0.64 \\
\hline \multirow{7}{*}{ Israel } & 0 & 4029 & 0.1 & 6000 & 840 & 0.14 & 0.14 \\
\hline & 4030 & 6876 & 0.14 & & & & \\
\hline & 6876 & 10684 & 0.21 & 18000 & 6120 & 0.34 & 0.44 \\
\hline & 10685 & 15263 & 0.32 & & & & \\
\hline & 15263 & 31923 & 0.34 & 66000 & 33000 & 0.50 & 0.56 \\
\hline & 31923 & 51612 & 0.48 & & & & \\
\hline & 51613 & $\ldots$ & 0.5 & 150000 & 75000 & 0.50 & 0.50 \\
\hline \multirow{7}{*}{$\begin{array}{l}\text { USA Married } \\
\text { Individuals } \\
\text { Filing } \\
\text { Separate }\end{array}$} & & & & \multirow[b]{2}{*}{6000} & & & \\
\hline & 0 & 8500 & 0.1 & & 600 & 0.10 & 0.10 \\
\hline & 8501 & 34500 & 0.15 & 18000 & 2700 & 0.15 & 0.18 \\
\hline & 34501 & 69675 & 0.25 & 66000 & 16500 & 0.25 & 0.29 \\
\hline & 69676 & 106150 & 0.28 & 150000 & 49500 & 0.33 & 0.39 \\
\hline & 106151 & 189575 & 0.33 & & & & \\
\hline & 189576 & $\ldots$ & 0.35 & & & & \\
\hline & & & & & & & \\
\hline & 0 & 50067 & 0.2 & 6000 & 1200 & 0.20 & 0.20 \\
\hline Ireland & 50069 & 0 & 0.41 & 18000 & 7380 & 0.41 & 0.52 \\
\hline ireiand & & & & 66000 & 27060 & 0.41 & 0.41 \\
\hline & & & & 150000 & 61500 & 0.41 & 0.41 \\
\hline & 1 & 6439 & 01 & 6000 & 600 & 0.10 & 010 \\
\hline $\mathbf{U}$ & 6441 & 73870 & 0.2 & 18000 & 3600 & 0.20 & 0.25 \\
\hline U.K. & 73873 & 346159 & 0.4 & 66000 & 13200 & 0.20 & 0.20 \\
\hline & 346159 & $\ldots$ & 0.45 & 150000 & 30000 & 0.20 & 0.20 \\
\hline & & & & & & & \\
\hline & 1 & 15207 & 0.16 & 6000 & 960 & 0.16 & 0.16 \\
\hline & 15209 & 30417 & 0.27 & 18000 & 4860 & 0.27 & 0.33 \\
\hline Slovenia & 30419 & $\ldots$ & 0.41 & 66000 & 27060 & 0.41 & 0.46 \\
\hline & & & & 150000 & 61500 & 0.41 & 0.41 \\
\hline & 0 & 54 & 0.019 & 600 & 648 & 0.11 & 027 \\
\hline & 54 & 460 & 0.064 & & & & \\
\hline & 460 & 808 & 0.108 & 1800 & 383.4 & 0.21 & 0.33 \\
\hline & 809 & 940 & 0.16 & & & & \\
\hline Mexico & 940 & 1125 & 0.179 & 6600 & 1980 & 0.30 & 0.30 \\
\hline & 1125 & 2269 & 0.213 & & & & \\
\hline & 2269 & 3122 & 0.235 & 15000 & 4500 & 0.30 & 0.30 \\
\hline & 3122 & 0 & 0.3 & & & & \\
\hline & & & & & & & \\
\hline & 0 & 228 & 0.05 & 600 & 120 & 0.20 & 0.40 \\
\hline & 228 & 386 & 0.1 & 1800 & 594 & 0.33 & 0.43 \\
\hline & 386 & 813 & 0.2 & 6600 & 2640 & 0.40 & 0.40 \\
\hline Japan & 813 & 1053 & 0.23 & 15000 & 6000 & 0.40 & 0.40 \\
\hline & 1053 & 2105 & 0.33 & & & & \\
\hline & 2105 & 0 & 0.4 & & & & \\
\hline & 1 & 5292 & 0.15 & 794 & 935.42 & 0.16 & 0.20 \\
\hline Turkey & 5292 & 12858 & 0.2 & 2307 & 3335.42 & 0.19 & 0.26 \\
\hline
\end{tabular}




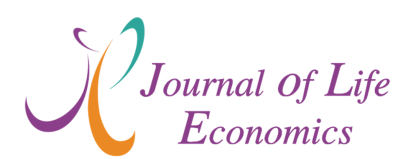

\begin{tabular}{|c|c|c|c|c|c|c|c|c|}
\hline & 12859 & 29673 & 0.27 & 6212 & & 15674.95 & 0.24 & 0.35 \\
\cline { 2 - 9 } & 29673 & $\ldots$ & 0.35 & & & 45074.95 & 0.30 & 0.30 \\
\hline
\end{tabular}

Source: (OECD Taxing Wage Statistics, http://www.oecd-ilibrary.org/taxation/data/taxingwages/comparative-tables_data-00265-en, 01.09.2017)

In tax policies that claim that the working preference is independent of an increase or decrease in tax rates, marginal tax rates may be increased as much as possible to achieve the required public income, but labor supply may react to changes in tax rates because they are not inelastic in all cases (Prescott, 2005: 124).Increased proportionality in taxation is important in order to shifting the burden to high-income persons, ensuring equality and justice principles, and positively impacting the decision to do business, especially in low-wage line of business (Kemmerling, 2009: 20). It is possible to achieve increasing proportionality in taxation in two ways (Kemmerling, 2009: 20):

i) Tax expenditures in the form of indirect deductions or exemptions for low incomes. It affects labor force participation in low-wage industries.

ii)Direct marginal tax rates are reduced. It is an application for high wages and working hours.

\section{Graph 20. Progressivity of Income Tax Structure in Different OECD Countries (Growth Rates from Average Tax Rate to Marginal Tax Rate in Different Scenarios)}

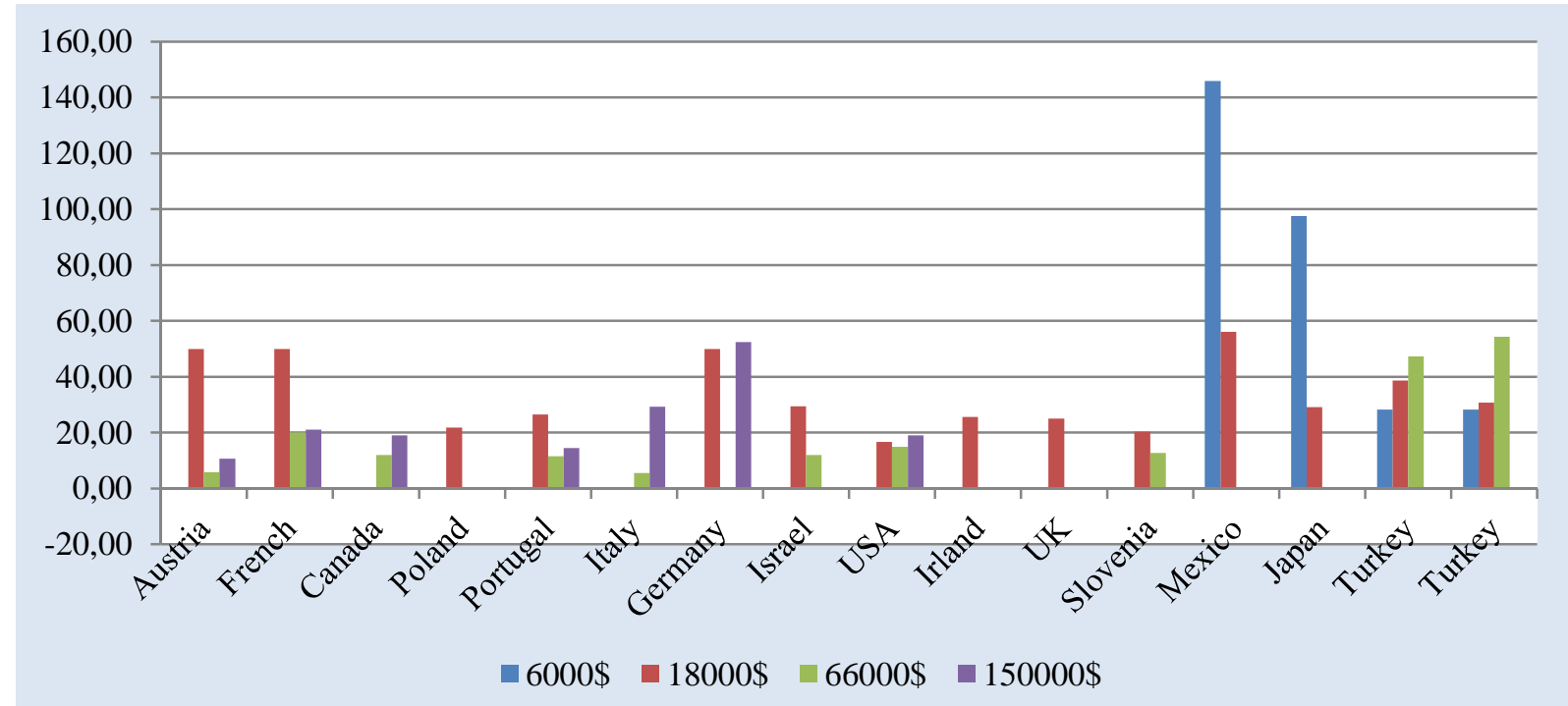

\section{Source:Own Calculation}

Graph (20) shows the progressivity is measured by using different annual income levels scenarios for different income levels (results from Table 1)(growth rates from average tax rate to marginal tax rate in different scenarios). In Mexico, Turkey and Japan, progressivity is lower for high income levels. This indicates that, marginal rates are lower for high income levels. In Canada, Italy, Germany and USA, progressivity has the highest values for high income levels.

In taxation, relation between family structure and progressivity must also be taken into account. While doing so, it is focused on the differences between one - earner and two earners married couple with two children. 


\section{Graph21.Regressivity / Progressivity of Family Taxation in Different OECD Countries (2004 - 2016) (for One-earner married couple at 100\% of average earnings, 2 children)}

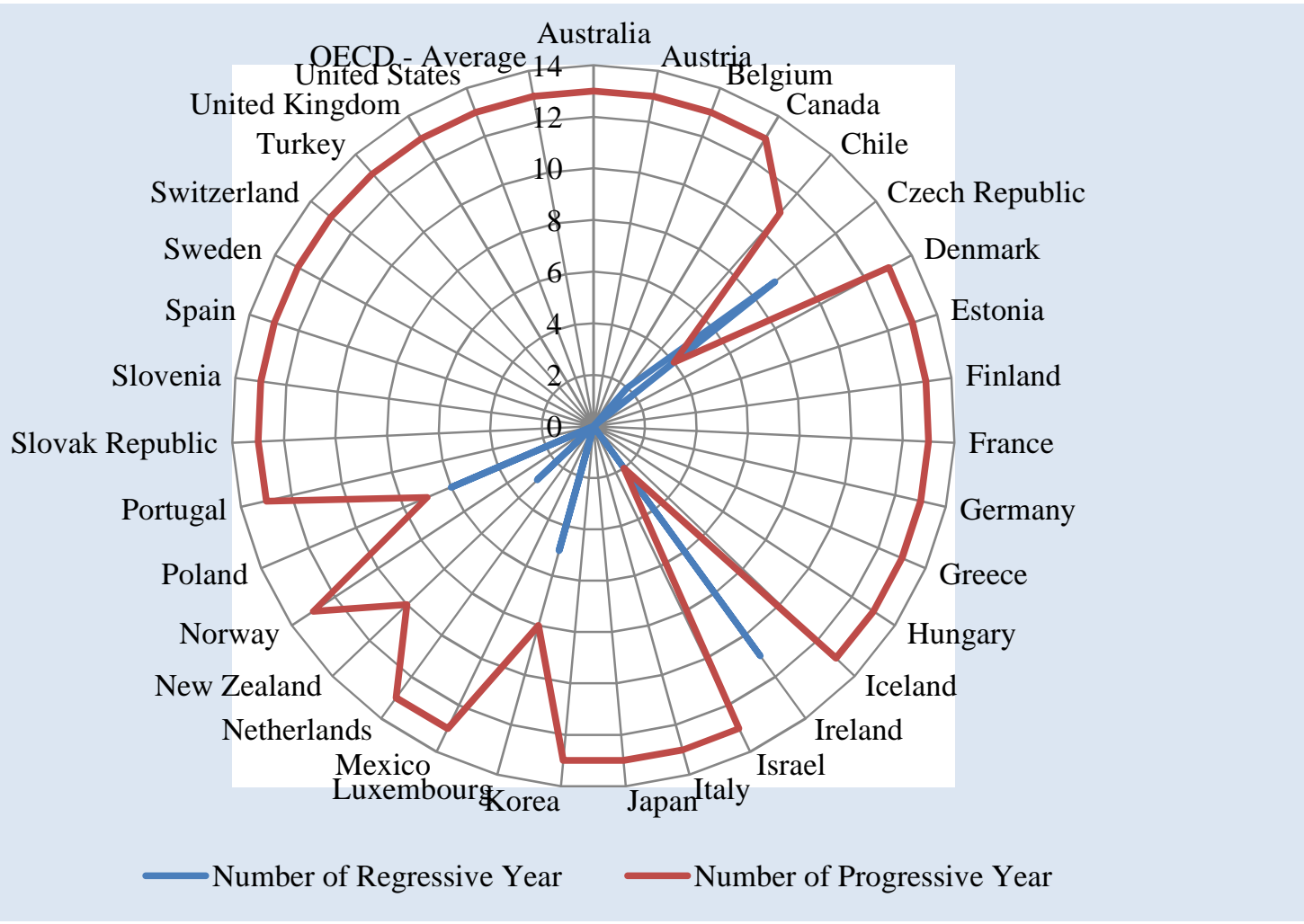

Source:(OECD Taxing Wage Statistics, http://www.oecd-ilibrary.org/taxation/data/taxingwages/comparative-tables_data-00265-en, 01.09.2017)

The Graph (21) shows the years in which countries put one-earner married couple practice into account (from net personal average tax rate to net personal marginal tax rate).Czech Republic, Ireland and Poland had used flat rates for more years. In other countries progressive character has continued. 


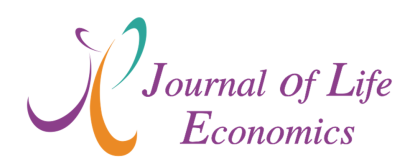

Graph 22.Regressivity / Progressivity of Family Taxation in Different OECD Countries (2004-2016) (for Two-earner married couple, one at 100\% of average earnings and the other at $33 \%, 2$ children)

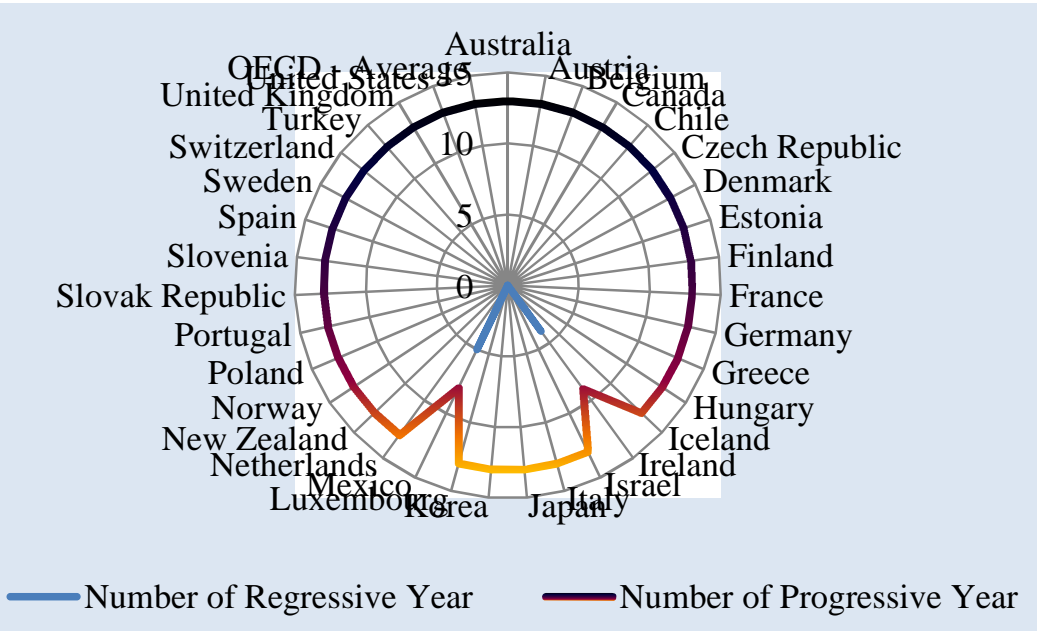

Source: (OECD Taxing Wage Statistics, http://www.oecd-ilibrary.org/taxation/data/taxingwages/comparative-tables_data-00265-en, 01.09.2017)

The Graph (22) shows the years in which countries put two-earner married couple, practice into account. Flat taxes can only be seen in Ireland and Mexico. Although the idea that progressivity provides justice in taxation is availablescientifically, those findings are interpreted that family structures which is possible to obtain more income, have much more advantageous arrangements.

\section{Graph 23.Average and Marginal Tax Rate for Different Family Structure in Some OECD Countries (Avr. 2004 - 2016)}

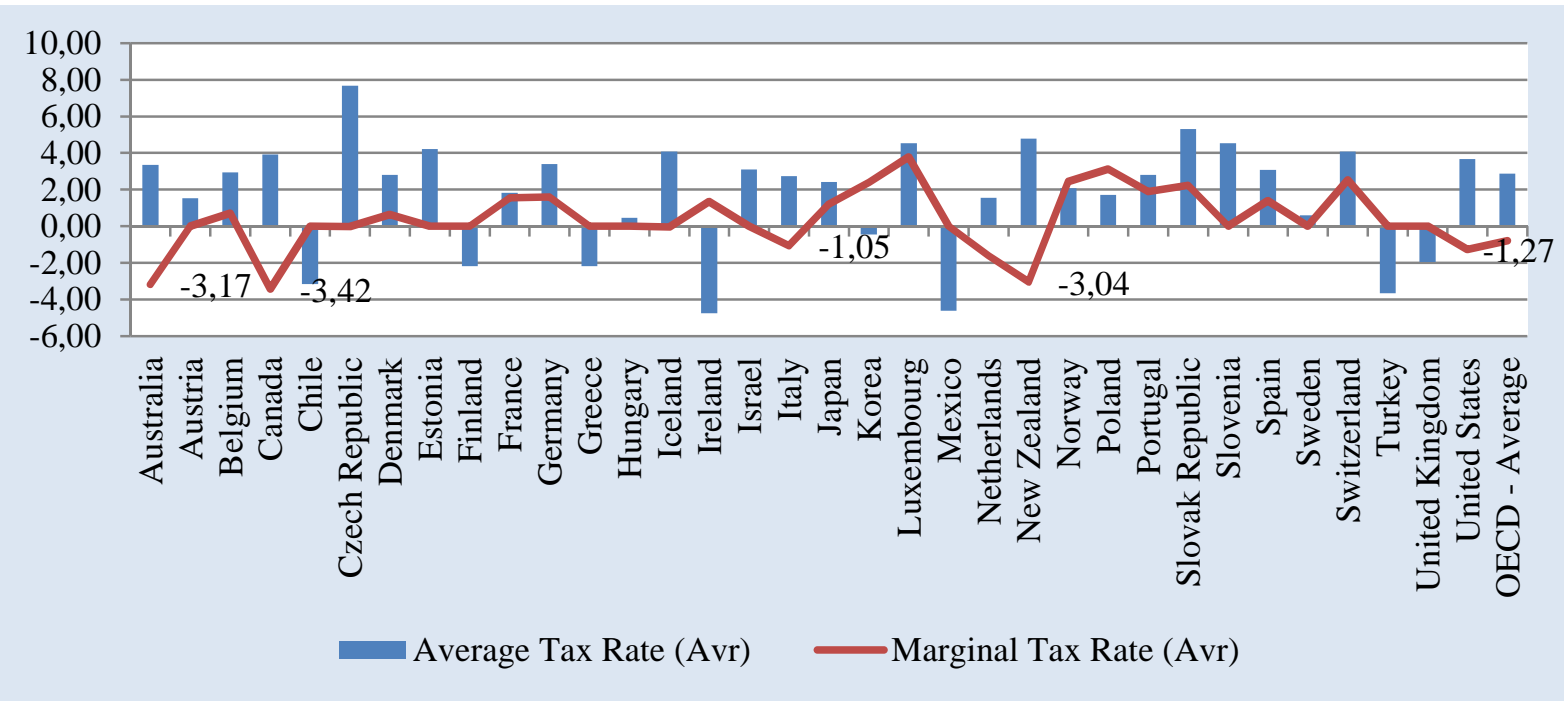

Source: (OECD Taxing Wage Statistics, http://www.oecd-ilibrary.org/taxation/data/taxingwages/comparative-tables_data-00265-en, 01.09.2017)

The Graph (23) shows relation between average and marginal rate differences and different family structures between one-earner and two-earner married couple. It is an interesting fact that marginal rates for high income families are smaller than for low income families in Australia, Canada, Italy, New Zealand and USA. 


\subsubsection{Tax Expenditures and Poverty Interaction (Mechanisms in Taxation)}

It is stated that it is necessary to exclude low income persons (especially the ones who earn wage income) from the total taxation or the significant tax such as income tax in order for taxation to be possible according to the ability to pay criteria (economic capacity) (Wagner, 1964: 14). Value added and sales taxes prevent the reduction of the tax burden on mandatory requirements, so it is stated that low-income taxpayers may be protected from tax increases by reducing wage tax rates rather than by excluding clothing and food expenditures from taxation.(Graetz, 2005: 60). The exemptions and reductions applied within the wage tax seem to reduce the disincentive effects of taxation on employment (Kemmerling, 2009: 35).

Disruptions in the tax structure lead to differences in economic structures among countries and can impair equality, efficiency and administrative convenience. Exemptions for the benefit of high-income individuals, for example; making the tax rates diminishing, leading to tax evasion and lowering government incomes (Cubero and Hollar, 2010: 33).Mechanisms in tax systems have also great importance on an amount of earning labour income and protection against lose. For this aim, several contribution and benefits must bu used for labour force. Net income should examined with this mechanisms.

Table 2. Taxes and Benefits in OECD Countries (change from 2011 to 2016)

(for single person 2 children)

\begin{tabular}{|c|c|c|c|c|c|c|c|}
\hline & & $\begin{array}{l}\text { Unemployment } \\
\text { Benefits }\end{array}$ & $\begin{array}{l}\text { Income } \\
\text { Tax }\end{array}$ & $\begin{array}{c}\text { Social } \\
\text { Contributions }\end{array}$ & $\begin{array}{l}\text { Housing } \\
\text { Benefits }\end{array}$ & $\begin{array}{l}\text { Family } \\
\text { Benefits }\end{array}$ & $\begin{array}{c}\text { Net } \\
\text { Income }\end{array}$ \\
\hline \multirow{2}{*}{ Australia } & Emp. & 0.00 & 2.71 & 0.00 & 2.91 & 2.83 & 3.33 \\
\hline & Unemp. & 0.00 & 13.00 & 0.00 & 2.75 & 3.04 & 3.08 \\
\hline \multirow{2}{*}{ Austria } & Emp. & 0.00 & 2.46 & 2.56 & 0.00 & 1.93 & 2.51 \\
\hline & Unemp. & 2.48 & 0.00 & 0.00 & 0.00 & 1.93 & 2.35 \\
\hline \multirow{2}{*}{ Belgium } & Emp. & 0.00 & 3.17 & 2.93 & 0.00 & 2.75 & 2.79 \\
\hline & Unemp. & 3.37 & 0.00 & 0.00 & 0.00 & 3.83 & 3.47 \\
\hline \multirow{2}{*}{ Canada } & Emp. & 0.00 & 3.13 & 2.34 & 0.00 & 1.05 & 2.71 \\
\hline & Unemp. & 2.59 & 9.04 & 4.13 & 0.00 & 3.46 & 3.18 \\
\hline \multirow{2}{*}{$\begin{array}{l}\text { Czech } \\
\text { Republic }\end{array}$} & Emp. & 0.00 & 4.61 & 8.22 & 0.00 & 4.61 & 7.69 \\
\hline & Unemp. & 7.86 & 0.00 & 0.00 & 4.61 & 5.01 & 7.48 \\
\hline \multirow{2}{*}{ Denmark } & Emp. & 0.00 & 4.47 & 2.49 & 4.61 & 4.61 & 1.95 \\
\hline & Unemp. & 1.83 & 4.61 & 4.61 & 4.41 & 4.37 & 2.65 \\
\hline \multirow{2}{*}{ Finland } & Emp. & 0.00 & 6.70 & 5.63 & 16.43 & 5.97 & 5.21 \\
\hline & Unemp. & 5.49 & 7.65 & 16.36 & 17.57 & 5.97 & 5.51 \\
\hline \multirow{2}{*}{ France } & Emp. & 0.00 & 4.43 & 4.42 & 0.00 & 4.45 & 4.22 \\
\hline & Unemp. & 4.25 & 4.50 & 4.61 & 4.61 & 4.45 & 4.31 \\
\hline \multirow{2}{*}{ Germany } & Emp. & 0.00 & 5.56 & 3.48 & 0.00 & 6.00 & 3.61 \\
\hline & Unemp. & 2.81 & 5.62 & 4.24 & 14.98 & 6.00 & 3.95 \\
\hline \multirow{2}{*}{ Greece } & Emp. & 0.00 & 4.03 & 3.73 & 0.00 & 4.08 & 2.13 \\
\hline & Unemp. & 3.54 & 14.21 & 14.00 & 4.54 & 4.08 & 1.73 \\
\hline \multirow{2}{*}{ Hungary } & Emp. & 0.00 & 5.57 & 4.92 & 0.00 & 7.24 & 4.29 \\
\hline & Unemp. & 5.61 & 0.00 & 0.00 & 4.55 & 7.24 & 5.18 \\
\hline \multirow{2}{*}{ Iceland } & Emp. & 0.00 & 4.60 & 4.59 & 0.00 & 4.60 & 4.59 \\
\hline & Unemp. & 4.60 & 4.61 & 4.61 & 4.61 & 4.60 & 4.60 \\
\hline \multirow{2}{*}{ Ireland } & Emp. & 0.00 & 4.41 & 4.97 & 4.61 & 2.87 & 3.55 \\
\hline & Unemp. & 3.90 & 4.61 & 2.90 & 4.40 & 3.53 & 3.76 \\
\hline \multirow{2}{*}{ Italy } & Emp. & 0.00 & 11.77 & 9.63 & 18.14 & 9.32 & 9.52 \\
\hline & Unemp. & 11.17 & 20.33 & 18.80 & 10.80 & 8.33 & 9.70 \\
\hline
\end{tabular}




\begin{tabular}{|c|c|c|c|c|c|c|c|}
\hline \multirow{2}{*}{ Japan } & Emp. & 0.00 & 2.51 & 4.02 & 0.00 & 5.16 & 4.13 \\
\hline & Unemp. & 4.08 & 11.78 & 0.00 & 12.37 & 6.45 & 3.90 \\
\hline \multirow{2}{*}{ Korea } & Emp. & 0.00 & 4.60 & 4.59 & 0.00 & 4.58 & 4.58 \\
\hline & Unemp. & 4.56 & 0.00 & 15.24 & 4.61 & 4.58 & 4.57 \\
\hline \multirow{2}{*}{ Luxembourg } & Emp. & 0.00 & 4.60 & 4.60 & 0.00 & 14.39 & 4.60 \\
\hline & Unemp. & 4.60 & 0.00 & 0.00 & 0.00 & 15.07 & 4.60 \\
\hline \multirow{2}{*}{ Netherlands } & Emp. & 0.00 & 9.31 & 9.44 & 0.00 & 8.59 & 9.21 \\
\hline & Unemp. & 8.61 & 8.45 & 4.61 & 20.80 & 8.59 & 9.07 \\
\hline \multirow{2}{*}{ New Zealand } & Emp. & 0.00 & 9.62 & 10.56 & 0.00 & 4.61 & 11.59 \\
\hline & Unemp. & 10.83 & 4.61 & 4.61 & 0.00 & 10.54 & 11.14 \\
\hline \multirow{2}{*}{ Norway } & Emp. & 0.00 & 3.48 & 7.13 & 0.00 & 3.91 & 2.65 \\
\hline & Unemp. & 5.16 & 2.97 & 15.56 & 4.61 & 3.07 & 4.52 \\
\hline \multirow{2}{*}{ Poland } & Emp. & 0.00 & 4.51 & 4.31 & 0.00 & 4.57 & 4.50 \\
\hline & Unemp. & 4.45 & 4.53 & 4.04 & 14.49 & 4.58 & 4.50 \\
\hline \multirow{2}{*}{ Portugal } & Emp. & 0.00 & 6.15 & 4.46 & 0.00 & 15.58 & 4.95 \\
\hline & Unemp. & 4.80 & 5.99 & 0.00 & 1.29 & 3.95 & 4.16 \\
\hline \multirow{2}{*}{$\begin{array}{l}\text { Slovak } \\
\text { Republic }\end{array}$} & Emp. & 0.00 & 8.78 & 7.67 & 0.00 & 8.60 & 7.98 \\
\hline & Unemp. & 7.98 & 17.92 & 17.16 & 0.00 & 9.69 & 7.99 \\
\hline \multirow{2}{*}{ Spain } & Emp. & 0.00 & 4.61 & 4.29 & 0.00 & 4.61 & 4.49 \\
\hline & Unemp. & 4.50 & 0.00 & 0.00 & 15.42 & 4.53 & 4.49 \\
\hline \multirow{2}{*}{ Sweden } & Emp. & 0.00 & 4.59 & 4.60 & 0.00 & 4.60 & 4.60 \\
\hline & Unemp. & 4.60 & 0.00 & 4.61 & 4.61 & 4.60 & 4.60 \\
\hline \multirow{2}{*}{ Switzerland } & Emp. & 0.00 & 3.90 & 1.48 & 0.00 & 13.28 & 3.98 \\
\hline & Unemp. & 4.21 & 4.61 & 4.61 & 0.00 & 15.03 & 3.76 \\
\hline \multirow{2}{*}{ Turkey } & Emp. & 0.00 & 3.40 & 4.16 & 0.00 & 0.00 & 4.27 \\
\hline & Unemp. & 4.32 & 5.65 & 0.00 & 0.00 & 0.00 & 4.30 \\
\hline \multirow{2}{*}{$\begin{array}{l}\text { United } \\
\text { Kingdom }\end{array}$} & Emp. & 0.00 & 4.59 & 4.42 & 0.00 & 4.58 & 4.55 \\
\hline & Unemp. & 4.54 & 4.60 & 4.37 & 4.58 & 4.56 & 4.54 \\
\hline \multirow{2}{*}{ United States } & Emp. & 0.00 & 3.98 & 4.50 & 0.00 & 4.61 & 4.20 \\
\hline & Unemp. & 4.30 & 4.47 & 4.52 & 0.00 & 4.61 & 4.28 \\
\hline
\end{tabular}

Source: (OECD Taxing Wage Statistics, http://www.oecd-ilibrary.org/taxation/data/taxingwages/comparative-tables_data-00265-en, 01.09.2017)

In Table 2, change in contributions and benefits for employed and nonemployed people between the years 2011 and 2016 can be seen. Yellow marked area shows the change between two periods. Taking PIT, unemployment relief and net income all together into account for nonemployed people; France, Iceland, Ireland, Japan, S. Korea, Luxembourg, Poland, Spain, Switzerland, UK and USA, have decreased their unemployment reliefs. Though there is a decrease PIT or an implicit subsidy for unemployed person, net income kept falling in France, Iceland, Ireland, Poland, Switzerland, UK and USA.In Denmark, France, Iceland and UK; social contributions, housing benefits and family benefits have all been decreased for nonemployed people. Altough unemployment relief have decreased and personal income tax have increased in Japan, net income has not decreased. This can be explained by other contribution and benefits. For the most of the countries, tax deductions in PIT are more and decrease in housing benefits are less for employed people. It can also be seen that, social contributions and family bennefits are deductable for employed people. 


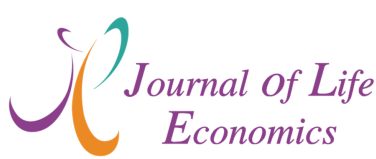

\subsection{Opportunity Cost of Resource Use and Poverty (Taxation versus Public Borrowing)}

At the center of philosophy of taxation, taxes are considered as common financement tools and that people take this burden only by comparing benefit of public goods they consume. But today this point view of has changed and taking this burden has became a question mark. Taxes are considered as common financial tools but today taking this burden has become a question mark. In Green (1993), it has a special emphasis on the transformation from "tax state" to "debt state" (Green, 1993: p. 29).

In this part of the analysis it will be focused on;how the sources

i) Which are required to reduce or for long period to eradicate the poverty are exploited in terms of debt dynamics

ii) As mentioned in Caskurlu (2011), create effects on narrowing fiscal space in terms of debt dynamics.

\section{Graph 24. The Relation Between Total Debt / GDP and Social Expenditures / GDP Growth Rate(2012 - 2015)}

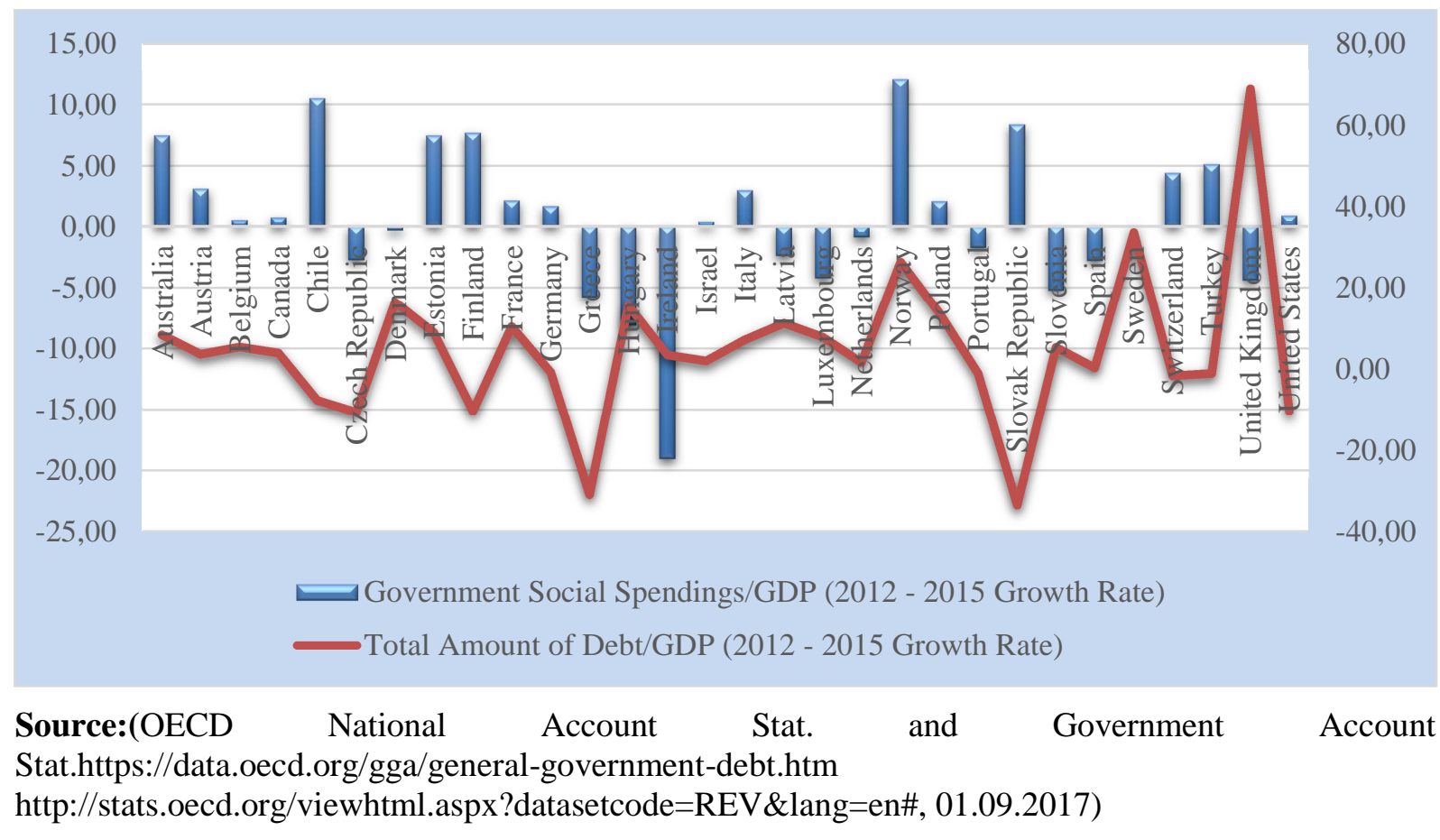

Graph (24) shows the relation between total debt / GDP and social expenditures / GDP growth rate for the years 2010 to 2015.There is a trade-off between all governmentsspending in terms of resource use. So social spendingis expected to decrease in years which government debt spendingincreases. Examples are Belgium, Canada, Denmark, France, Hungary, Ireland, Israel, Italy, Latvia, Luxemburg, Netherlands, Poland, Slovenia, UK.

In Hungary, Latvia, Luxembourg and UK, indebtedness has risen most drastically and social expenditures have fallen significantly. Inversely, in Turkey, Chile, Finland, Germany, Slovak Rep. and Switzerland, indebtedness has fallen and social expenditures have risen. But in Turkey although public debts have fallen, private sectors indebtedness has risen significantly. This is a vital risk factor for government, even though these are not written in public accounts. 


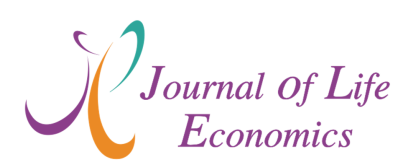

The rise of debts in one period $(\mathrm{t})$, is expected to come up with a tax revenue increase in succeeding one or two periods $(t+1$ or $t+2)$ after, because of repayment. And this is the situation of tax - debt dependence which means that tax systems focus on financial issues and cannot be used for the fight against poverty.

\section{Graph 25.The Correlation Between the Growth Rate of "Central Government Debt / GDP” and Growth Rate of Tax Revenues (2012 - 2015)}

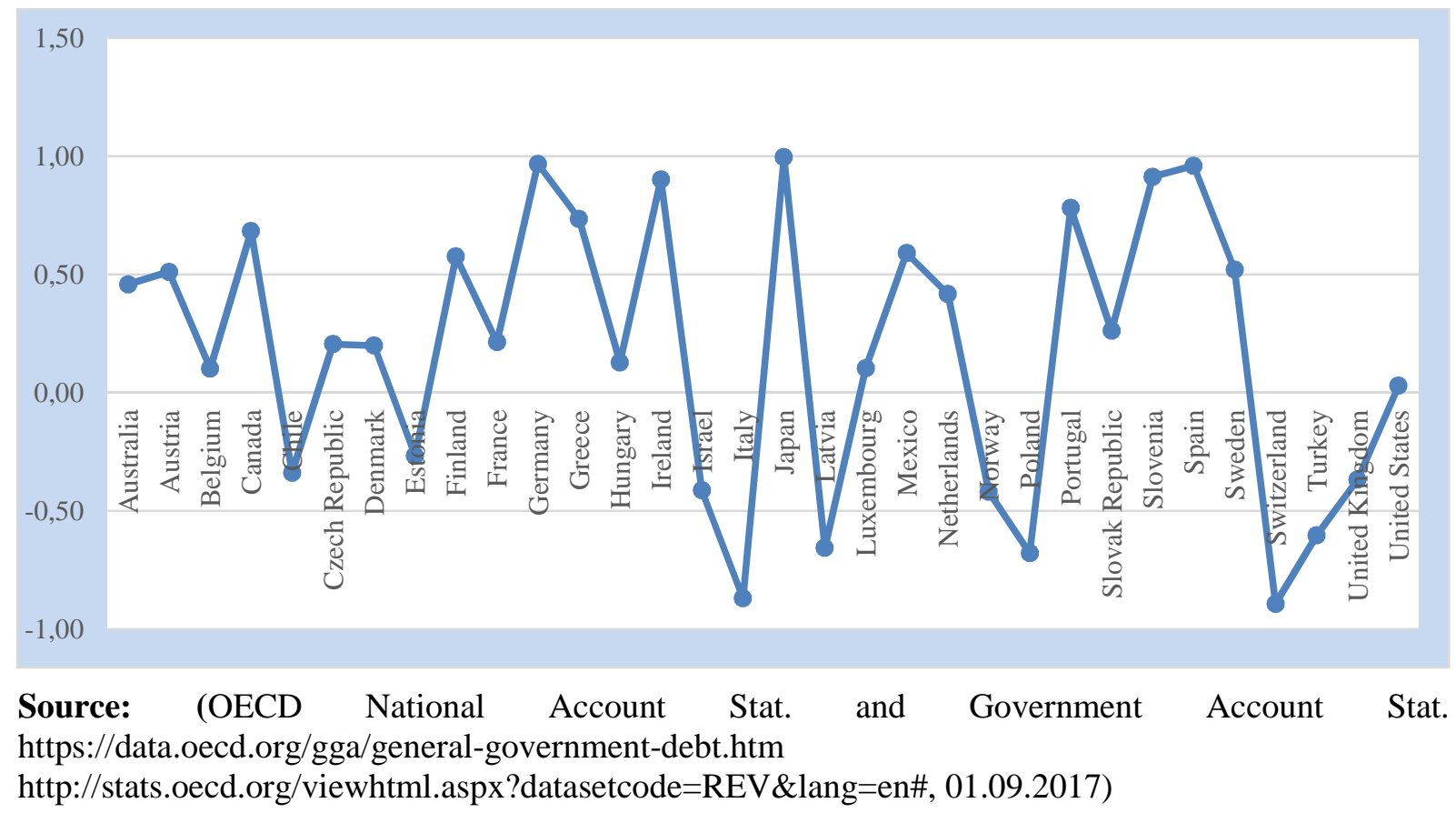

Graph (25) shows the correlation between the growth rate of "central government debt / GDP" and growth rate of tax revenues. In 35\% of OECD countries, an incremental relation was seen. This indicates a dependent relation between tax revenues and public borrowing. Increase in public debts, can be an answer to the question of which expenditures are financed through tax revenues or tax burden.

\section{CONCLUSIONS AND FINAL REMARKS}

Poverty is a concrete fact which is brought about by the current economic system and is emerged as a result of certain preferences. It is not a usually encountered, spontaneous or side effect problem. So, the ideal is not reduction of poverty but alleviation of poverty.

Taxes are important both in terms of ensuring the necessary financing for government activities and being an important tool of economic policy in scope. Taxes function in the fulfillment of many targets, from resource allocation to income distribution and economic growth. Besides that, taxes create heavy burdens on taxpayers. So "redistribution via taxation" gains importance for the social matter as "poverty".

Considering the trade-off between generating resources for economic growth and being just in taxation, governments should announce the aims of their tax system design.Especially in countries with high income inequalities, tax systems shouldnot deepen these kinds of problems.In taxation, it should always be kept in mind that people who face poverty gap, doesnot have enough ability to pay.In Taylor (2007), it is mentioned that the most appropriate way to reduce economic dependency and the drain of the welfare state is to reduce the burden of tax on the poorest in society. 


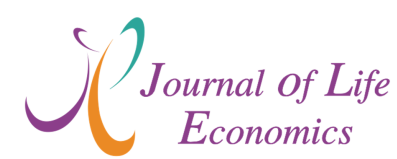

Tax structures affect preferences to work (labor time) or not to work (leisure time) and bring income and substitutions effects into existence and also stimulate labor supply in the shadow economy. Tax distortions may happen through redistributive side of taxation. Besides, taxation compatible with the world system adopts the general understanding that tax deficit is closed over wage by decreasing the tax burden on profit, the problem of distribution maintains its severity. When economic and social conditions are being taken into account in taxation, the fact of "family" has an importance. In this paper, findings show that when a family's income level increases, tax income increases 3 to 1 proportion in comparison with the other group after. Those findings are interpreted also that family structures which is possible to obtain more income, have much more advantageous arrangements. Redistributive arrangements in taxation like; social contributions, housing benefits and family benefits have all been decreased for non-employed people in many OECD countries in the examining years. Finally, an important and vital factor which especially effects fight against poverty by taxation is tax - debt dependence.

Albeit countries in search of the need for resources for growth and development, attach importance to the distribution of welfare in society's interest, opportunities to conduct independent policies of those countries are taken away. No factor except labor acquires income with its own effort, but, labor is subjected to the highest tax burden within its income acquired due to class characteristics. Even the difference in declaration and form of payment of tax can change tax burden. Capital gains are taxed with taxpayer's declarations barring exceptions and the collection period is the following year after income is acquired. The endeavor to attain income is fewer, the power of income acquired is higher and taxation is less wearing.

Struggles of members of social classes can assure gains such as fair distribution and taxation. The duty to satisfy income inequalities and regulate elements, which make the burden heavier albeit the effort the working class displays when acquiring income is considerable, in favor of the proletariat falls on the social state, in which the participation of labor organizations and their representatives is of considerable extents. Awareness of the proletariat expanding and acting together as a class constitute the most essential gains that will facilitate to generate the pressure that can eliminate unjust tax regulations and to raise welfare. 


\section{REFERENCES}

AGARWAL, P., The Lorenz Curve and Gini Coefficient, Macroeconomics, https://www.intelligenteconomist.com/lorenz-curve-gini-coefficient/, 02.010.2017.

AKSAN, G., 2012,Yoksulluk ve Yoksulluk Kültürünün Toplumsal Görünümleri, Selçuk Üniversitesi Sosyal Bilimler Enstitüsü Dergisi, 27,9-19.

AKTAN, C. C. and VURAL, İ.,Y., 2002, Yoksulluk: Terminoloji, TemelKavramlarveÖlçümYöntemleriCoşkun Can Aktan (ed.), Yoksullukla Mücadele Stratejileri, Ankara: Hak-İ̧̧KonfederasyonuYayınları.

AL, A., 2015, Politika-Ekonomi Kesişmesi: Yeni Bir Bilim Dalı Olarak Uluslararası Politik Ekonomi, İstanbul GelişimÜniversitesiSosyalBilimlerDergisi, Cilt: 2 Sayı: 1, Nisan, 143-159.

$\begin{array}{lllll}\text { ATEŞ, } & \text { D., } & \text { GÖKMEN, } & \text { S. }\end{array}$ BirAkademikDisiplinOlarakUluslararasıPolitikEkonomininSınırları, AfyonKocatepe ÜniversitesiSosyalBilimlerDergisi, Cilt: XV, Say1: 1, 45-71.

AYYILDIZ, F. V., 2017, Gelir Adaletsizliğinin Sebeplerinin Araştırılması: Ampirik Analiz, KARADENIZ, (34), 131-141.

BALSEVEN,H., 2017, Refah Devleti Ve Gelir Dağılımı: Karşılaştırmalı Bir Analiz, C. $\ddot{U}$. Iktisadi ve Ídari Bilimler Dergisi, Cilt: 18, Say1: 1, 87-107.

BESSARD, P. 2009, Tax Burden And Individual Rights In TheOECD: An International Comparison, Institut Constant de Rebecque / Tax burden and individual rights in the OECD, Switzerland.

BIRD, R. 2010, Taxation and Development, The World Bank, Poverty Reduction and Economic Management Network (PREM), October, Number 34, www.worldbank.org/economicpremise.

BRYS, B., MATTHEWS S. and OWENS J., 2011, Tax Reform Trends in OECD Countries, OECD Taxation Working Papers, No. 1, OECD Publishing.

ÇAŞKURLU, E., 2011, Political Economy of Tax Structure in a World Where Capital Globalized and Class Inequalities: Tax Analysis Aimed at Wage Earners in Turkey in Globalization Dimensions and Impacts,Global Studies Series Vol. 1, Ed. İsmail Şiriner and LubomirNenicka, IJOPEC Publication, London, 203-228.

CUBERO, R. and HOLLAR, I. V., 2010, Equity And Fiscal Policy: The Income Distribution Effects Of Taxation And Social Sepending In Central America,IMF Working Paper, WP/10/112.

DEMIR, İ. C., 2013, Türkiye'de Vergi Yükü (Objektif ve Subjektif Yönleriyle), Dora Yayınları, Bursa.

EDIZDOĞAN, N. and ÇELIKKAYA, A., 2010,VergilerinEkonomikAnalizi, DoraYayınları, Bursa.

FJELDSTAD, O.H. and MOORE, M., 2008, Tax Reform And State - Building In A Globalised World, In D. A. Brautigam, O. H. Fjeldstadand M. Moore (Ed.), Taxation And State - Building In Developing Countries, UK: Cambridge University Press, 235-260. 
GEMMELL, N. and MORRISSEY, O., 2002, The Poverty Impacts of Revenue Systems in Developing Countries, A Report to the Department for International Development, Technical Report, https://assets.publishing.service.gov.uk/media/57a08bede5274a27b2000e6f/R7617 _FinalReport10Jan.pdf

GRAETZ, M. J., 2005, A Fair And Balanced Tax System For The Twenty - First Century, In A. J. Auerbach\& K. A. Hassett (Ed.), Toward Fundamental Tax Reform, USA: The AEI Press, 48-68.

GREEN, C., 1993, From "tax state" to "debt state", Journal of Revolutionary Economics, 3,23-42.

HATİPLER, M., 2017,Neoliberalizmin Öteki Yüzü: Yoksulluğun Küreselleşme Kaldıracı, Uluslararası Bilimsel Araştırmalar Dergisi,2(5), 77-87. http://dx.doi.org/10.1787/5kg3h0xxmz8t-en

ITRIAGO, D. 2011, Owning Development Taxation To Fight Poverty, Intermón Oxfam, Oxfam Research Report.

JOUMARD, I, PISU, M. and BLOCH, D., 2012, Tackling Income Inequality: The Role of Taxes and Transfers, OECD Journal: Economic Studies, http://dx.doi.org/10.1787/eco_studies-2012-5k95xd6165lt

KEMMERLING, A. 2009, Taxing The Working Poor, UK: Edward Elgar Publishing Limited.

KIZILOT, Ş. ÇOMAKLI, Ş. VergiKayıpVeKaçaklarıVeKayıtdışıEkonomiIlişkisiVeBoyutlarınınMevzuatAçısında nDeğerlendirilmesi.T.C. UludağÜniversitesi İ.İ.B.F MaliyeBölümü, XIX.TürkiyeMaliyeSempozyumu: Türkiye'deVergiKayıpVeKaçakları, ÖnlenmesiYolları, YaklaşımYayıncılık, Ankara, 115-157.

KORKMAZ, E. 1982, VergiYapısıVeGelişimi, İktisatFakültesiYayınları, Yayın No:489, Gür Ay Matbaas1, İstanbul.

MARTIN, X. S, SAMANS, R. and BLANKE, J., 2016, The Global Competitiveness Report 2016-2017, World Economic Forum, Global Competitiveness and Risks Team., Ed. Klaus SCHWAB, Geneva.

MULligAN, C. B. 2005, Political And Economic Perspective On Taxes' Excess Burdens. In A. J. Auerbachand K. A. Hassett (Ed.), Toward Fundamental Tax Reform, USA: The AEI Press, 95-105.

OCAMPO, J. A. and CARMONA, M. S., 2015, Tax Avoidance By Corporations Is Out Of Control,The United Nations Must Step In, The Guardian,https://www.theguardian.com/commentisfree/2015/sep/30/tax-avoidancecorporations-impacts-the-poor-united-nations-step-in

OECD,ILibrary Statistics, http://www.oecd-ilibrary.org/statistics;jsessionid=fn80oliaktomb.xoecd-live-02, 09.09.2017.

ONARAN O., BOSCH, V. and LEIBRECHT, M., 2010, How Does Globalization Affect The Tax Burden On Labour Income, Capital Income And Consumption In Different Welfare Regimes? The Case Of Western And Eastern EU Member States, Discussion Paper No. 35, International Tax Coordination, SBFI. 
ÖNIŞ, Z., and KUTLAY, M. 2014, UluslararasıPolitikEkonomi, UluslararasıllişskilereGiriş: Tarih, Teori, KavramveKonular, Ed. ŞabanKardaşand Ali Balcı, İmgeYayınları, Ankara, 1-11.

OYAN, O. 1998, TürkiyeEkonomisi: NeredenNereye?,Türk - İşYayınları, İmajYayınevi,Ankara.

ÖZERKMEN, N., Uluslararası Eşitsizliği Derinleştiren Bir Süreç Olarak Ekonomik Küreselleşme, Ankara Üniversitesi Dil ve Tarih Coğrafya Fakültesi Dergisi, 44, 1, 135-148.

PICOS-SÁNCHEZ, F., 2011, Consumption Taxation as an Additional Burden on Labour Income, OECD Taxation Working Papers, No. 7, OECD Publishing, http://dx.doi.org/10.1787/5kg3h0t4xlq4-en

PRESCOTT, E. C. 2005, The Elasticity Of Labor Supply And The Consequences For Tax Policy, In A. J. Auerbachand K. A. Hassett (Ed.), Toward Fundamental TaxReform, USA: The AEI Press, 123 - 134

SCHNEIDER, F., 2015, Size and Development of the Shadow Economy of 31 European and 5 other OECD Countries from 2003 to 2015: Different Developments, January 20,http://www.econ.jku.at/members/Schneider/files/publications/2015/ShadEcEuro pe31.pdf

SCHNEIDER, F., BUEHN, A., MONTENEGRO, C.E., 2010, Shadow Economies All over the World: New Estimates for 162 Countries from 1999 to 2007, Policy Research Working Paper, 5356, The World Bank Development Research Group Poverty and Inequality Team \& Europe and Central Asia Region Human Development Economics Unit, July.

SCHWARZ, P. 2012, Tax Disincentives And Female Employment In Organisation For Economic Co-Operation And Development (OECD) Countries, Journal of European Social Policy, Vol 22, Issue 1, 17- 29.

ŞEN, A., 1998, UluslararasıPolitikEkonomi (UPE) Nedir?,Atatürk ÜniversitesiİktisadiveİdariBilimlerDergisi, Cilt: 12, Say1: 1-2, 393-408.

SPADARO, A., 2008, Optimal Taxation, Social Contract And The Four Worlds Of Welfare Capitalism,Paris School of Economics, Working Paper No.2008-38.

TANZİ, V., 1987, Tax System and Policy Objectives in Developing Countries: General Principles and Diagnostic Test,SimplificaciónTributaria(Revista de AdministraciónTributaria, No. 3, Enero, CIAT/IEF/CIAT, 23-34, http://www.ciat.org/index.php/en/products-and-services/library/on-linelibrary.html, 11.11.2016.

TAYLOR, C., 2007, Tax Burden Highest For ThePoorest Households,For Immediate Release, Nesearch Note 13, https://d3n8a8pro7vhmx.cloudfront.net/taxpayersalliance/pages/364/attachments/or iginal/1427906105/poorest-highest-tax-burden.pdf?1427906105

UZUN, A. M., 2003, Yoksulluk Olgusu ve Dünya Bankası, C.Ü. Íktisadi ve İdari Bilimler Dergisi, Cilt 4, Say1 2, 155-173.

WAGNER, A. 1964, Three Extracts On Public Finance. In R. A. Musgrave \& A. T. Peacock (Ed.),Classics In The Theory Of Public Finance, UK \& USA: MacMillan \&Co. Ltd. and St. Martin's Press, 1-15. 
$\int\left(\begin{array}{c}\text { Journal of Life } \\ \text { Economics }\end{array}\right.$ 